\title{
Oncolytic Virotherapy: From Bench to Bedside
}

\author{
Ludi Yang ${ }^{1,2 \dagger}$, Xiang Gu ${ }^{1,2 \dagger}$, Jie Yu ${ }^{1,2 \dagger}$, Shengfang Ge ${ }^{1,2 * \dagger}$ and Xianqun Fan ${ }^{1,2 *}$ \\ ${ }^{1}$ Department of Ophthalmology, Ninth People's Hospital, Shanghai JiaoTong University School of Medicine, Shanghai, China, \\ ${ }^{2}$ Shanghai Key Laboratory of Orbital Diseases and Ocular Oncology, Shanghai, China
}

OPEN ACCESS

Edited by:

He Zhang,

Tongji University, China

Reviewed by:

Luisa Accardi,

National Institute of Health (ISS), Italy

Xiaofei Zhi,

Columbia University, United States

*Correspondence:

Shengfang $\mathrm{Ge}$

geshengfang@hotmail.com

Xianqun Fan

fanxq@sjtu.edu.cn

${ }^{\dagger}$ These authors have contributed equally to this work.

Specialty section:

This article was submitted to Molecular and Cellular Pathology,

a section of the journal

Frontiers in Cell and Developmental

Biology

Received: 06 October 2021 Accepted: 12 November 2021

Published: 26 November 2021

Citation:

Yang L, Gu X, Yu J, Ge S and Fan X (2021) Oncolytic Virotherapy: From

Bench to Bedside.

Front. Cell Dev. Biol. 9:790150.

doi: $10.3389 /$ fcell.2021.790150
Oncolytic viruses are naturally occurring or genetically engineered viruses that can replicate preferentially in tumor cells and inhibit tumor growth. These viruses have been considered an effective anticancer strategy in recent years. They mainly function by direct oncolysis, inducing an anticancer immune response and expressing exogenous effector genes. Their multifunctional characteristics indicate good application prospects as cancer therapeutics, especially in combination with other therapies, such as radiotherapy, chemotherapy and immunotherapy. Therefore, it is necessary to comprehensively understand the utility of oncolytic viruses in cancer therapeutics. Here, we review the characteristics, antitumor mechanisms, clinical applications, deficiencies and associated solutions, and future prospects of oncolytic viruses.

Keywords: oncolytic virus, tumor, immunity, mechanisms, clinical applications

\section{BACKGROUND}

Cancer is the second leading cause of death worldwide with increased number of cases and cancer deaths. According to estimates by the WHO, in the next 20 years, the number of global cancer cases may increase by $60 \%$, and cancer is a huge burden on society worldwide (Siegel et al., 2021). The effects of traditional treatment modalities remain limited. In recent years, several strategies such as immunotherapy and targeted therapy have been developed and have shown the potential to improve the outcome of numerous malignancies.

Oncolytic viruses are a novel type of multimechanistic therapeutic agent for cancer treatment and have the advantages of immunotherapy and targeted therapy (Kaufman et al., 2016). Modifying the genome of the oncolytic virus improves its tumor-targeting capability and oncolytic potential. Meanwhile, the host's antitumor immunity can also be enhanced to achieve the purpose of treating cancer (Ramelyte et al., 2021). Oncolytic viruses are presently under evaluation in clinical and experimental trials, and some clinical research has demonstrated that oncolytic viruses significantly improve the prognosis of cancer patients and have a good safety profile (Lawler et al., 2017). In this review, we focus on the characteristics of oncolytic viruses and their mechanisms in tumor treatment. We discuss combinatorial strategies with other traditional treatments and immunotherapies and the challenges of oncolytic virotherapy.

\section{CHARACTERISTICS OF ONCOLYTIC VIRUSES}

Viruses are particles that must parasitize living cells, causing infection and a related immune response (Boivin et al., 2002). The naked virion is composed of the core and the capsid (Lee et al., 2017; Miranda-Saksena et al., 2018). The core of the virus comprises one type of nucleic acid (DNA or RNA). This nucleic acid makes up the virus genome, storing all the genetic information of the 
TABLE 1 | The unique characteristics of oncolytic virus.

\begin{tabular}{|c|c|c|c|c|c|c|c|c|c|}
\hline & \multicolumn{4}{|c|}{ DNA } & \multirow{2}{*}{$\frac{\text { RNA }}{\text { Paramyxovirus }}$} & \multirow[t]{2}{*}{ Rhabdovirus } & \multirow[t]{2}{*}{ Picornavirus } & \multirow[t]{2}{*}{ Togavirus } & \multirow[t]{2}{*}{ Reovirus } \\
\hline & Parvovirus & Adenovirus & Herpesvirus & Poxvirus & & & & & \\
\hline & ssDNA & dsDNA & dsDNA & dsDNA & ss (-)RNA & ss (-)RNA & ss (+)RNA & ss (+)RNA & dsRNA \\
\hline Genome size & 5-6 kb & $26-45$ kb & $120-240$ kb & $130-280$ kb & $15.2-15.9 \mathrm{~kb}$ & $11-15$ kb & $7-8 \mathrm{~kb}$ & $9.7-11.8 \mathrm{~kb}$ & $\begin{array}{l}10 \\
\text { segments of } \\
\text { double- } \\
\text { stranded } \\
\text { (ds) RNA }\end{array}$ \\
\hline $\begin{array}{l}\text { Virion } \\
\text { Capsid } \\
\text { symmetry }\end{array}$ & $\begin{array}{l}\text { Naked } \\
\text { Icosahedral }\end{array}$ & $\begin{array}{l}\text { Naked } \\
\text { Icosahedral }\end{array}$ & $\begin{array}{l}\text { Enveloped } \\
\text { Icosahedral }\end{array}$ & $\begin{array}{l}\text { Enveloped } \\
\text { Complex }\end{array}$ & $\begin{array}{l}\text { Enveloped } \\
\text { Helical }\end{array}$ & $\begin{array}{l}\text { Enveloped } \\
\text { Helical }\end{array}$ & $\begin{array}{l}\text { Naked } \\
\text { Icosahedral }\end{array}$ & $\begin{array}{l}\text { Enveloped } \\
\text { Icosahedral }\end{array}$ & $\begin{array}{l}\text { Naked } \\
\text { Icosahedral }\end{array}$ \\
\hline VAP & NA & $\begin{array}{l}\text { spike or fiber } \\
\text { associated } \\
\text { with each } \\
\text { penton base } \\
\text { of the capsid }\end{array}$ & $\begin{array}{l}\text { gp350/ } \\
\text { gp220 }\end{array}$ & $\begin{array}{l}\text { A27L, } \\
\text { M115L, A26 }\end{array}$ & $\mathrm{HA}$ & $g p G$ & VP1-VP3 & E1, E2 & $\sigma 1 \mathrm{~s}$ \\
\hline Cell receptor & $\begin{array}{l}\text { Sialic acid } \\
\text { residues }\end{array}$ & $\begin{array}{l}\text { CAR, CD46, } \\
\text { VCAM1 }\end{array}$ & $\begin{array}{l}\text { HVEM, nectin } \\
1, \text { nectin } 2\end{array}$ & GAGs, EFC & $\begin{array}{l}\text { SLAM, CD46, } \\
\text { Neuraminidase } \\
\text { Receptor, } \\
\text { sialoglycoconjugates }\end{array}$ & LDLR & $\begin{array}{l}\text { CD155, CAR, } \\
\text { ICAM-1, DAF }\end{array}$ & $\begin{array}{l}\text { phospholipid } \\
\text { receptors }\end{array}$ & JAM-A \\
\hline $\begin{array}{l}\text { type of } \\
\text { penetration }\end{array}$ & Viropexis & Viropexis & Viropexis & Fusion & Fusion & Viropexis & Viropexis & Viropexis & NA \\
\hline $\begin{array}{l}\text { Ability to } \\
\text { penetrate BBB }\end{array}$ & + & - & - & - & $-/+$ & - & $-1+$ & + & + \\
\hline $\begin{array}{l}\text { transgene } \\
\text { capacity }\end{array}$ & + & ++ & +++ & +++ & + & + & + & NA & +++ \\
\hline Immunogenicity & + & - & - & - & - & - & $+/-$ & + & - \\
\hline Antivirals & - & + & + & + & - & - & - & NA & - \\
\hline
\end{tabular}

NA, not applicable.

virus and controlling its characteristics (Guerra et al., 2017). Enveloped viruses consist of a nucleocapsid wrapped in an envelope (Parvez, 2020). With the development of genetic engineering and virology techniques, it is now possible to modify the structure of viruses to make them useful for human therapy; as examples, inactivated viruses can be used for vaccines, viral vectors can be used for genetic engineering, and viruses can also be used for cell fusion in cell engineering (Khattar et al., 2011; Song and Viskovska, 2020).

Oncolytic viruses are a special type of virus that are naturally or genetically engineered and can replicate preferentially in tumor cells and inhibit tumor growth (Jennings et al., 2019; Harrington et al., 2019). According to the type of nucleic acid they contain, oncolytic viruses can be divided into DNA viruses and RNA viruses (Table 1) (Bommareddy et al., 2018a). The differences between DNA and RNA viruses are as follows. Compared with RNA viruses, the advantage of DNA viruses is that most DNA viruses can express high-fidelity polymerases, ensuring genetic integrity and efficient replication. (Kaufman et al., 2016). However, DNA viruses have many disadvantageous characteristics. First, the ability of DNA viruses to induce immunogenicity is not as good as that of RNA viruses. Reasons for this include inefficient viral DNA delivery levels and inadequate DNA-sensing machinery and nucleic acidsensing pattern recognition receptor expression levels (McNamara et al., 20152015). Second, there is also a risk that viral DNA will integrate into the host genome, inactivating tumor suppressors or activating oncogenes (Liu, 2019). Third, most
RNA oncolytic viruses have more efficient delivery processes and are more advantageous for specifically killing central nervous system tumors. RNA oncolytic viruses are much smaller than DNA viruses, and they spread more easily throughout the human body, they can even cross the blood-brain barrier (Yu et al., 2011).

\section{MECHANISMS OF ONCOLYTIC VIRUSES}

\subsection{Selectivity}

Tumor cells are different from normal cells in terms of genetics and physiology. As a result of the abnormal antiviral ability and signaling pathways of tumor cells and tumor-specific promoters or mRNAs, oncolytic viruses can specifically target tumor cells without replicating and growing in healthy cells. In addition, the differential expression of apoptosis-related genes or surface receptor proteins between tumor and normal cells is also important for virus targeting. The selectivity of viruses is an inherent guarantee of their safety in clinical applications.

Antiviral signaling pathways (such as the IFN pathway) in normal cells can eliminate viruses. In tumor cells, there are mutations or deletions among the key protein-coding genes of these signaling pathways. Therefore, oncolytic viruses can use dysregulated signaling pathways in tumor cells to promote virus replication, infection and spread (Stewart et al., 2011; Ilkow et al., 2014; Kurokawa et al., 2018). The matrix (M) protein is commonly present in negative stranded RNA viruses, lining the inner side of the envelope of the virions. The $M$ protein of 
Vesicular stomatitis virus (VSV) is a structural protein and virulence factor that plays a significant role in virus assembly and suppression of host gene expression. $M$ protein variants retain virus assembly functions but can not inhibit host IFN gene expression. VSVs expressing M protein variants cannot replicate in normal tissue cells due to the activation of the IFN signaling pathway. However, they can selectively replicate in tumor cells with defective IFN immune responses (Stewart et al., 2011). In addition, there are other abnormal nonimmune signaling pathways in tumor cells. For example, ICP4 is a key protein required for HSV replication that can be activated by ELK, a downstream protein of RAS. A mutant HSVwhose expression of ICP4 is controlled by activation of ELK has the selective ability because the RAS signaling pathway is generally silent in normal cells, while it is activated in tumor cells (Pan et al., 2009). Some wild-type viruses, such as reovirus, have shown a good natural preference for tumor cells with overactive RAS, and these viruses can function without engineering (Shmulevitz et al., 2005; Carew et al., 2017).

Some specific promoters can regulate the transcription and expression of key viral replication genes. Controlling key viral expression genes with such promoters can restrict the virus from being highly expressed in tumor tissues (Deweese et al., 2001; Cheng et al., 2015; Zhang et al., 2015). E2F-1 (Tsukuda et al., 2002), hTERT (Sato et al., 2013) and HIF-1 (Longo et al., 2011) are promoters with high expression in tumor tissues and low expression in normal tissues. Placing a key viral replication gene (such as E1A and E1B) under these specific promoters stimulates the expression of the key gene in tumor tissues, which can enhance the selectivity of the virus (Yoon et al., 2001).

Inserting tissue-specific miRNA sequences into the oncolytic virus genome can also regulate the expression of key genes, preventing the replication of viruses in normal tissue cells (Yao et al., 2014). miR199 is a miRNA that is downregulated in hepatocellular carcinoma (HCC) compared to in the normal liver (Lou et al., 2018). Adenovirus-199T (Ad-199T) is a recombinant adenovirus in which copies of DNA segments complementary to miR199 are inserted within the essential adenovirus replication gene E1A. Ad-199T can replicate in cells lacking miR-199 to make virus replication and cytolytic effects specifically selective for HCC cells (Callegari et al., 2013).

Viral selectivity can also be achieved by targeting key genes that play an important role in viral replication in normal cells. The genes themselves have to be unrelated to the replication of the virus in the tumor. The E1B- $55 \mathrm{~K}$ protein, which prevents premature apoptosis, is expressed among wild-type adenoviruses (Dix et al., 2000). The p53 gene is an important apoptosisinducing gene in normal cells. Inactivation of the p53 gene is an important feature of tumor cells. Viral replication depends on the inhibition of host cell apoptosis, which is related to the function of p53. An oncolytic adenovirus with E1B gene deletion cannot replicate in normal cells due to the dysfunction of apoptosis inhibition, while in p53-deficient tumor cells, replication is not affected (Bischoff et al., 1996).

Another way to make a virus tumor-specific is genetically modifying the viral capsid protein to achieve tumor cell-specific binding. For example, uPAR is a highly expressed receptor on the

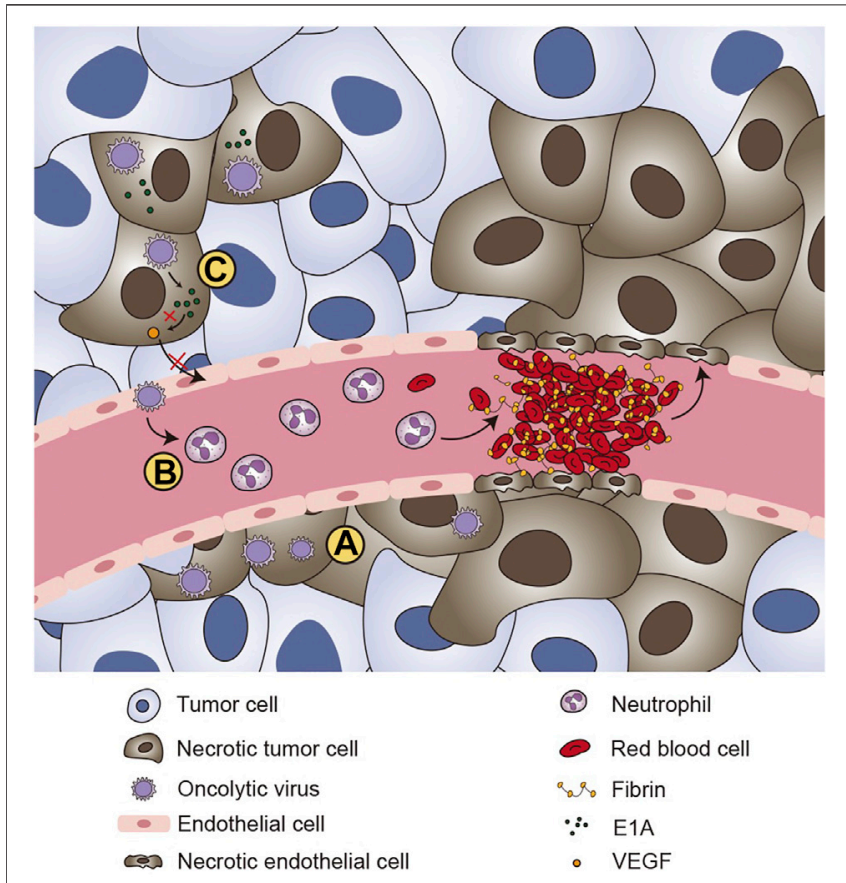

FIGURE 1 | The effects of tumor lysis of oncolytic virus. (A) Oncolytic viruses are able to kill tumor cells directly. (B) After infecting the endothelium of the tumor vasculature, oncolytic viruses are able to recruit neutrophil cells and mediate the formation of clots and vascular collapse, which induce the ischemic death of tumor cells. (C) VEGF plays an important role in the regulation of angiogenesis and tumor growth. Some specific oncolytic viruses, such as adenovirus, can express the E1A protein, which can downregulate VEGF by interacting with angiogenic proteins, thereby affecting new blood vessels in the tumor microenvironment and ultimately achieving oncolytic effects.

surface of a variety of tumor cells. UPAR is closely related to tumor aggressiveness and angiogenesis. The MV-h-uPA construct contains an added fragment that binds to UPAR and can specifically infect tumor cells with high expression of UPAR through the receptor-ligand pathway (Jing et al., 2014). Furthermore, inserting lysine residues into ciliated proteins allows the virus to bind to tumor cells that widely express heparin sulfate receptors. HER-2, a surface molecule, is hyperexpressed in 15-20\% mammary and ovary carcinomas. HSV can be engineered to target HER2 by replacing the Igfolded core in the receptor-binding virion glycoprotein $\mathrm{D}$ with an anti-HER-2 single-chain antibody (Menotti et al., 2009). HSV also mediates highly efficient infection in glioblastoma cells in which EGFR is highly expressed, by combining engineered viral glycoproteins, gD and gB (Uchida et al., 2013).

\subsection{Tumor Lysis}

The effects of tumor lysis can be categorized into direct effects on cells and effects on tumor vasculature (Figure 1).

Oncolytic viruses use tumor cells as a processing factory and replicate in large quantities. During proliferation, the oncolytic virus can block the synthesis of cellular nucleic acids and proteins, which causes cell metabolism dysfunction and ultimately lyses 
tumor cells. In addition, the nucleus, lysosomes, endoplasmic reticulum and mitochondria of the infected cells can all be damaged as a result of high viral replication volumes. In addition to the effects of replication, the structures of oncolytic viruses, such as the capsid protein, can also cause direct oncolysis.

Tumor neovascularization is a key mechanism by which tumors maintain their growth and development (Lugano et al., 2020). Inhibiting tumor neovascularization can cut off the supply of tumor oxygen and nutrients, thereby inhibiting tumor growth and metastasis (Qian and Pezzella, 2018). Oncolytic viruses have potent antiangiogenic properties and can induce vascular collapse, which in turn causes tumor cell death (Gholami et al., 2016). HSV is able to infect the endothelium of the tumor vasculature by recruiting inflammatory cells that lead to the formation of local microthrombi (Breitbach et al., 2007). This phenomenon has been verified in various cancers, such as ovarian cancer, glioma, and rhabdomyosarcoma. Breitbach C. et al. revealed that vaccinia viruses (VVs) can replicate within endothelial cells of the tumor-associated vasculature (Breitbach et al., 2013). Over time, the tumor's blood vessel density gradually decreases, and neutrophils continue to accumulate, resulting in decreased tumor cell perfusion and the ischemic death of tumor cells. Vascular endothelial growth factor (VEGF) is a highly specific vascular endothelial cell growth factor. It plays critical roles in the migration, proliferation and angiogenesis of vascular endothelial cells, which are closely related to tumor progression. Adenovirus can express E1A protein, which can downregulate VEGF by interacting with angiogenic cell proteins, thereby affecting new blood vessels formation in the tumor microenvironment and ultimately achieving oncolytic effects (Ye et al., 2006).

\subsection{Antitumor Immunity \\ 3.3.1 Innate Immunity}

Tumor cells and their microenvironment usually express cytokines (such as IL-10 and TGF $\beta$ ) with immunosuppressive functions, which inactivate effector immune cells and recruit immunosuppressive cells to the tumor (Borsig, 2018). In some cases, there are few immune cells in the tumor microenvironment, which is known as a "cold" microenvironment. Oncolytic viruses are capable of reversing this immunosuppressive microenvironment, turning "cold" tumors into "hot" tumors by changing the cytokine environment and promoting immune cell maturation (Galon and Bruni, 2019).

Following viral infection, oncolytic viruses can induce the death of tumor cells by mediating immunogenic cells. Viral elements (tumor-associated antigens (TAAs) and viral pathogen-associated molecular patterns (PAMPs)) and cellderived damage-associated molecular patterns (DAMPs) can be released (Yoo et al., 2013). Pattern recognition receptors (PRRs) such as the family of Toll-like receptors can recognize TAAs, PAMPs and DAMPs and trigger MYD88-dependent and TRIF-dependent signaling (Chen et al., 2018). In addition, there are other sensing elements, such as RIG-I-like receptors (RLRs: RIG-1 and MDA5), PKR and cyclic GMP-AMP synthase
(cGAS)-stimulator of interferon genes (STING). PKR, RIG-I and MDA5 recognize RNA, while the cytosolic sensor cGAS detects DNA. RIG-I and MDA-5 are thought to recognize ssRNA and dsRNA, stimulating the release of NF- $\kappa$ B, IRF3, and IRF7(Lin et al., 2019). In the process of viral infection and invasion, cytoplasmic DNA is recognized as a danger signal by the DNA sensor cGAS, and the downstream protein STING is used as an adaptor molecule to recognize cGAMP and activate downstream signals to promote the production of type I interferons and other cytokines (Kato et al., 2017).

These cytokines play a critical role in the recruitment and activation of innate immune cells, such as dendritic cells (DCs) and natural killer (NK) cells, which can reverse the immunosuppressive microenvironment in tumors. For example, dendritic cells loaded with human melanoma Mel888 cells (DC-Mel) cannot normally respond to PRR-PAMP signaling, which leads to low antitumor immunity. Reovirus can reverse the dysfunction of DCs-Mel by upregulating the secretion of costimulatory factors and cytokines. Reovirus can reduce the secretion of IL-10 from immunosuppressive cells and induce the production of proinflammatory factors such as the macrophage inflammatory protein MIP- $1 \alpha / \beta$. These cytokines can activate DCs and mediate a variety of immune responses (Prestwich et al., 2009).

\subsubsection{Adaptive Immunity}

Most tumor cells do not express MHC molecules or express them at a low level, resulting in tumor cells that lack or weakly present tumor antigens. Such tumor cells do not induce cytotoxic $\mathrm{T}$ lymphocyte (CTL) activation; thus, no immune-system-based tumor-cell killing occurs (Axelrod et al., 2019). Oncolytic viruses are capable of promoting DC maturation and increasing their antigen presentation ability (Raja et al., 2018). Mature DCs (mDCs) can present antigenic peptides on MHC I and $\mathrm{MHC}$ II molecules to $\mathrm{CD} 8^{+}$and $\mathrm{CD} 4^{+} \mathrm{T}$ cells, respectively, and deliver costimulatory signals that activate $\mathrm{T}$ cells (Pardee et al., 2015). In a murine ovarian cancer model, J. Patrick Murphy et al. revealed that tumor MHC-1 ligand expression was increased after treatment with oncolytic reovirus (Murphy et al., 2019). An increase in MHC was detected not only in tumor cells but also in spleen tissues. The same results were also observed in CMT64 lung adenocarcinoma cells infected with oncolytic adenovirus. In a model in which DCs are incubated with tumor cells, tumor cells not infected with reoviruses cannot induce the killing response of cytotoxic T cells, but this response can be induced by infected tumor cells (Figure 2).

As a new potential cancer therapy, oncolytic viruses can prevent tumor recurrence by establishing immune memory in the body. Minjun Yu et al. induced lymphoma regression in mice by administering Sindbis virus vectors in combination with a41BB monoclonal antibodies (Yu et al., 2019). In addition, all mice treated with Sindbis virus vectors and a4-1BB monoclonal antibodies were proven to have durable antitumor immune memory. Havunen et al. constructed an oncolytic adenovirus with insertion of the human IL-2 gene and the human tumor necrosis factor $a$ (hTNF- $\alpha$ ) gene (Havunen et al., 2017). They combined the transformed adenovirus with tumor-infiltrating 


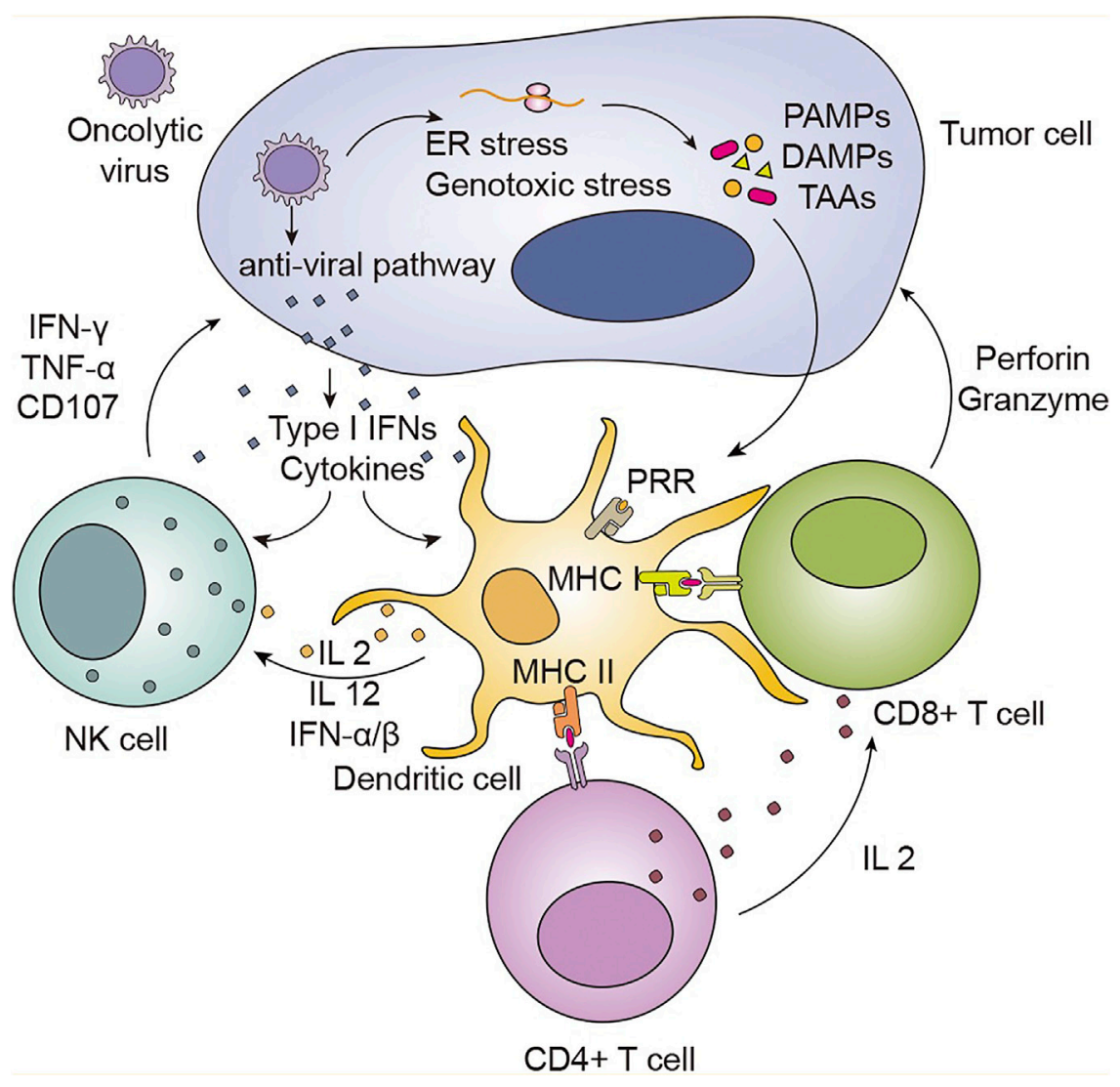

FIGURE 2 | Oncolytic viruses can induce host systemic anti-tumor immunity to kill tumor cells. Following viral infection, viral replication leads to ER stress and genotoxic stress in tumor cells, which results in the release of the viral elements TAAs, PAMPs, and DAMPs. Sensing elements, such as PRRs, can recognize these molecules, which leads to immune cell activation and inflammatory signal transduction. With virus replication, antiviral pathways can be activated. This activation induces the production of cytokines and type I IFNs, which mediate the activation and maturation of immune cells, such as DCs and NK cells. NK cells migrate to the tumor area under the action of chemokines, such as IL-12, IL-2, and IFN- $\alpha / \beta$, and exert antitumoral properties by releasing IFN- $\gamma$, TNF- $\alpha$ and CD107. Mature DCs can present antigenic peptides within the context of $\mathrm{MHC}$ I molecules to $\mathrm{CD} 4^{+} \mathrm{T}$ cells and within the context of MHC II molecules to $\mathrm{CD} 8^{+} \mathrm{T}$ cells. CD8 ${ }^{+} \mathrm{T}$ cells are also activated through the stimulation of CD4 ${ }^{+} \mathrm{T}$ cells. The activation of $\mathrm{CD} 4^{+} \mathrm{T}$ cells by DCs helps to activate $\mathrm{CD} 8^{+} \mathrm{T}$ cells by inducing the production of cytokines such as IL-2. The recognition of tumor surface antigens by antibodies can trigger CTL killing of tumor cells through Fas-FasL interactions, TNF-TNFR signaling, and the perforin/granzyme pathway.

lymphocytes (TILs) to form the Ad5/3-E2F-d24-hTNFa-IREShIL2 (TILT-123) strategy, which was tested in Syrian hamsters with tumors formed from transplanted pancreatic cancer cells. The results indicated that oncolytic viruses carrying the IL-2 and TNF- $\alpha$ genes could increase the frequency of $\mathrm{CD} 4^{+}$and $\mathrm{CD} 8^{+}$ TILs and strengthen the persistence and proliferation of $\mathrm{T}$ cells. After treatment, Syrian hamsters were again inoculated with the same pancreatic cancer cells, and the tumor recurrence rate was lower than that of Syrian hamsters that received oncolytic virus treatment alone.

\subsection{Transgene Expression}

Oncolytic viruses can also be genetically modified to serve as vectors to express therapeutic genes to kill tumor cells in multiple ways, effectively avoiding the current common drug resistance problem of single-target anticancer drugs (Marino et al., 2017). This strategy is known as "arming" and is similar to combining an oncolytic virus with a cancer-killing "accomplice".

\subsubsection{Suicide Genes}

Suicide gene therapy is known as virus-directed enzymatic prodrug therapy (VDEPT) (Zhang et al., 2010; Karjoo et al., 2016). Suicide gene therapy involves the introduction of a gene encoding a specific sensitivity factor into tumor cells, which causes the cells to be specifically sensitive to a specific originally nontoxic or low-toxicity drug, thereby causing tumor cell death. This expressed sensitivity gene is called a suicide gene or a drug sensitivity gene. T601 is a VV with TK and RR knocked out that expresses the fusion suicide gene FCU1(Foloppe et al., 2019). FCU1 is a product of the fusion of the yeast cytosine deaminase gene and the uracil phosphoribosyltransferase gene (Husseini et al., 2017). Yeast cytosine deaminase can convert the prodrug 5-FC into the chemotherapeutic drug 5-fluorouracil (5-FU), while uracil phosphoribosyltransferase can further convert 5-FU into 5fluorouracil triphosphate (FUTP) and 5-fluorodeoxyuracil monophosphate (FdUMP). FUTP inhibits the activity of RNA, 
and FdUMP inhibits the synthesis of DNA and can reduce the degradation of 5-FU, thereby killing tumor cells (Dias et al., 2010).

\subsubsection{Anti-angiogenesis Genes}

Angiogenesis is essential for tumor progression. It has been proven that angiogenesis inhibitors have antitumor effects. Endostatin and angiostatin are two broad-spectrum angiogenesis inhibitors (Gonzalez et al., 2018). However, endostatin and angiostatin have no direct tumor cell killing effect and must be continuously transported to the tumor microenvironment. Due to their short half-life in serum, low solubility and poor stability, angiostatin and endostatin cannot function in a traditional manner (Marshall, 2002). Oncolytic viruses genetically modified to continuously express angiogenesis inhibitors in the tumor microenvironment can inhibit angiogenesis factors and significantly reduce the activation and migration of endothelial cells (Indraccolo et al., 2002). Hutzen B et al. constructed the measles virus (MV) variants MV-hE: A and MV-Me. These viruses can express human and mouse endostatin/angiostatin fusion proteins, respectively. In medulloblastoma, the target gene is continually expressed as the oncolytic virus replicates, which leads to the inhibition of angiogenesis factors and induces the death of tumor cells. (Hutzen et al., 2014).

\subsubsection{Immune-Related Genes}

Inserting cytokine-related genes into the oncolytic virus genome can effectively increase the local immune inflammatory mediators in the tumor microenvironment, thereby activating the body's antitumor immune response and enhancing the antitumor effect of the oncolytic virus. To date, various cytokine genes have been used to generate recombinant oncolytic viruses, such as interleukin, colony-stimulating factor, tumor necrosis factor, and chemokine genes (Zhu et al., 2012; Conrad et al., 2015; Hirvinen et al., 2015; BourgeoisDaigneault et al., 2016; Deng et al., 2016). GM-CSF is currently the most widely used cytokine in clinical practice (Chon et al., 2019). It has been integrated into the genomes of various oncolytic viruses and has shown a certain degree of therapeutic efficacy in preclinical studies (Liu et al., 2013). The first oncolytic virus approved by the FDA, T-VEC, is a version of HSV-1 with GM-CSF inserted into its genome (Andtbacka et al., 2015).

In addition, viruses can be engineered to express other immune factor genes to enhance the body's antitumor immune response. The oncolytic virus G47 $\Delta$-IL-12, derived from an HSV-1 strain, has a strong oncolytic effect on malignant gliomas (Saha et al., 2017). This virus can significantly promote the killing of tumor cells and virusinfected cells by expressing IL-12. A preclinical model showed that monotherapy with IL12-expressing HSV is sufficient to eradicate glioma and provides resistance to rechallenge with high-grade gliomas, even without immune checkpoint blockade (Alessandrini et al., 2019). Ad-ZD55 is an adenovirus derived from the deletion of the E1B-55 $\mathrm{kD}$ gene (Liu and $\mathrm{Gu}$, 2006). Ad-ZD55-TRAIL and Ad-ZD55-IL-24 are viruses derived from Ad-ZD55 with the TRAIL gene and IL-24 gene inserted, respectively (Zhao et al., 2006). TRAIL and IL-24 can interact and promote each other, further inducing substantial tumor apoptosis by activating intracellular tumor-killing mechanisms. Oncolytic adenoviruses can express the chemokines MIP-1 $\alpha$ or RANTES, which induce the recruitment of DCs and enhance the antitumor immune response (Edukulla et al., 2009).

\subsubsection{Tumor Microenvironment Related Genes}

The formation of the tumor microenvironment may prevent oncolytic viruses from exerting their effects. To eliminate the unfavorable factors caused by the tumor microenvironment, viruses can be genetically modified or altered by other methods to enhance their efficacy. The extracellular matrix (ECM) of solid tumors can affect the infection and spread of therapeutic viruses (Mok et al., 2007). Matrix-degrading enzymes improve tumor permeability by degrading ECM, increasing the spread of viruses and the concentration of viruses in tumor cells. Li et al. constructed an oncolytic adenovirus expressing decorin (DCN) (Li et al., 2018). The results of their experiments showed that the virus mediated the expression of DCN, which downregulated the main components of the ECM (such as collagens I and III), in pancreatic cancer tumor tissues. This effect resulted in the accelerated spread of the virus in mice with pancreatic tumors in situ and induced tumor cell apoptosis.

\section{ONCOLYTIC VIRUSES IN CANCER}

Given the antitumor properties of oncolytic viruses, a variety of oncolytic viruses with tumor-killing effects have been developed. The clinical applications of oncolytic viruses are introduced below according to their types (TABLE 2).

\subsection{Different Types of Viruses \\ 4.1.1 Adenoviruses}

Adenoviruses are non-enveloped viruses with double-stranded DNA genomes (Greber and Flatt, 2019). They have a large genome (approximately $35 \mathrm{~kb}$ ), which is convenient for genetic modification (Shen et al., 2009). Human adenovirus (HAdV) can be divided into more than 50 serotypes, which can be classified into seven species (HAdV-A to -G) (MarrugalLorenzo et al., 2019). CG0070 and ONYX-015 are two classic examples of oncolytic adenoviruses. CG0070 has antitumor activity by expressing the immunoregulatory factor GM-CSF. Nagarajan Ramesh et al. investigated antitumor efficacy of CG0070 in several bladder transitional cell carcinoma models, which has shown good tumor specificity and oncolytic effects (Ramesh et al., 2006). Barker et al. used ONYX-015, which has a deletion of the E1B gene, in the therapy of head and neck cancer, pancreatic cancer and recurrent granulation tumors, The objective remission rate of patients in clinical trials has been improved (Barker and Berk, 1987). Studies of Ilya V Ulasov et al. showed that CRAd-S-pk7 cells selectively target and penetrate tumor metastases, effectively delivering the CRAd-S-pk7 virus (Ulasov et al., 2007). Ilya V Ulasov established the effectiveness and safety 
TABLE 2 | Oncolytic virus anti-tumor clinical trials.

\begin{tabular}{|c|c|c|c|c|c|c|c|}
\hline Virus & Modification & $\begin{array}{c}\text { Virus } \\
\text { administration }\end{array}$ & Status & Indication & $\begin{array}{l}\text { Therapeutic } \\
\text { Approach }\end{array}$ & Clinical trials & Status \\
\hline \multicolumn{8}{|l|}{ Adenovirus } \\
\hline DNX-2401 & $\Delta 24-R G D$ insertion & Intratumoural & 1 & Glioblastoma, ovarian cancer & $\begin{array}{l}\text { Combination or } \\
\text { OV only }\end{array}$ & $\begin{array}{l}\text { NCT03178032 } \\
\text { NCT01956734 }\end{array}$ & $\begin{array}{l}\text { Active } \\
\text { Completed }\end{array}$ \\
\hline VCN-01 & $\mathrm{PH} 20$ hyaluronidase & Intratumoural & 1 & $\begin{array}{l}\text { Pancreatic cancer, } \\
\text { Retinoblastoma, Head and Neck } \\
\text { Neoplasms } \\
\text { Osteosarcoma }\end{array}$ & $\begin{array}{l}\text { Combination or } \\
\text { OV only }\end{array}$ & $\begin{array}{l}\text { NCT03799744 } \\
\text { NCT03284268 }\end{array}$ & Recruiting \\
\hline CG0070 & $\begin{array}{l}\text { GM-CSF and E3 } \\
\text { deletion }\end{array}$ & Intratumoural & $|-|||$ & Bladder Cancer & $\begin{array}{l}\text { Combination or } \\
\text { OV only }\end{array}$ & $\begin{array}{l}\text { NCT04610671 } \\
\text { NCT02365818 }\end{array}$ & $\begin{array}{l}\text { Recruiting } \\
\text { Completed }\end{array}$ \\
\hline Colo-Ad1 & $\begin{array}{l}\text { Chimeric Ad11/3 } \\
\text { group B }\end{array}$ & Intratumoural & 1 & $\begin{array}{l}\text { Colon cancer, NSCLC, Renal cell } \\
\text { carcinoma, Bladder cancer }\end{array}$ & OV only & NCT02053220 & Completed \\
\hline ICOVIR5 & $\begin{array}{l}\text { Modified DNX-2401- } \\
\text { E2F promoter } \\
\text { opimitized }\end{array}$ & Intravenous & $|-| \mid$ & Melanoma, Solid Tumors & OV only & $\begin{array}{l}\text { NCT01864759 } \\
\text { NCT01844661 }\end{array}$ & $\begin{array}{l}\text { Completed } \\
\text { Completed }\end{array}$ \\
\hline $\begin{array}{l}\text { Ad5-yCD/ } \\
\text { mutTKSR39rephIL12 }\end{array}$ & $\begin{array}{l}\text { Ad serotype } 5 \text {; } \\
\text { insertion of IL12, } \\
\text { yeast cytosine } \\
\text { deaminase and } \\
\text { TKSR39 }\end{array}$ & Intratumoural & 1 & $\begin{array}{l}\text { Prostate Cancer, Pancreatic } \\
\text { Cancer }\end{array}$ & OV only & $\begin{array}{l}\text { NCT02555397 } \\
\text { NCT03281382 }\end{array}$ & $\begin{array}{l}\text { Recruiting } \\
\text { Recruiting }\end{array}$ \\
\hline $\mathrm{H} 101$ & $\begin{array}{l}\text { E1B deletion, partial } \\
\text { E3 deletion }\end{array}$ & Intratumoural & $|-|||$ & $\begin{array}{l}\text { Hepatocellular Carcinoma and } \\
\text { head and neck cancer }\end{array}$ & Combination & $\begin{array}{l}\text { NCT03790059 } \\
\text { NCT03780049 }\end{array}$ & $\begin{array}{l}\text { Recruiting } \\
\text { Recruiting }\end{array}$ \\
\hline ProstAtak & TK insertion & Intratumoural & $\|-I\|$ & Prostate Cancer & $\begin{array}{l}\text { Combination or } \\
\text { OV only }\end{array}$ & $\begin{array}{l}\text { NCT01436968 } \\
\text { NCT02768363 }\end{array}$ & $\begin{array}{l}\text { Recruiting } \\
\text { Active }\end{array}$ \\
\hline \multicolumn{8}{|l|}{ Herpesvirus } \\
\hline T-VEC & $\begin{array}{l}\text { ICP34.5 deletion, } \\
\text { US11 deletion, GM- } \\
\text { CSF insertion }\end{array}$ & Intratumoural & $|-|||$ & $\begin{array}{l}\text { Melanoma, head and neck } \\
\text { cancer and pancreatic cancer }\end{array}$ & $\begin{array}{l}\text { Combination or } \\
\text { OV only }\end{array}$ & $\begin{array}{l}\text { NCT03086642 } \\
\text { NCT03069378 } \\
\text { NCT01368276 }\end{array}$ & $\begin{array}{l}\text { Recruiting } \\
\text { Recruiting } \\
\text { Completed }\end{array}$ \\
\hline HF10 & $\begin{array}{l}\text { UL56 deletion, } \\
\text { selected for single } \\
\text { partial copy of UL52 }\end{array}$ & Intratumoural & $|-| \mid$ & $\begin{array}{l}\text { Breast cancer, melanoma, and } \\
\text { pancreatic cancer }\end{array}$ & $\begin{array}{l}\text { Combination or } \\
\text { OV only }\end{array}$ & $\begin{array}{l}\text { NCT03153085 } \\
\text { NCT03259425 }\end{array}$ & $\begin{array}{l}\text { Completed } \\
\text { Terminated }\end{array}$ \\
\hline HSV1716 & ICP34.5 deletion & Intratumoural & $|-| \mid$ & $\begin{array}{l}\text { Malignant Pleural Mesothelioma, } \\
\text { Rhabdomyosarcoma, } \\
\text { Osteosarcoma, Anaplastic } \\
\text { Oligodendroglioma }\end{array}$ & $\begin{array}{l}\text { Combination or } \\
\text { OV only }\end{array}$ & $\begin{array}{l}\text { NCT01721018 } \\
\text { NCT00931931 } \\
\text { NCT02031965 }\end{array}$ & $\begin{array}{l}\text { Completed } \\
\text { Completed } \\
\text { Terminated }\end{array}$ \\
\hline G207 & $\begin{array}{l}\text { ICP34.5 deletion } \\
\text { UL39 disruption }\end{array}$ & Intratumoural & $|-| \mid$ & Glioblastoma & OV only & $\begin{array}{l}\text { NCT03911388 } \\
\text { NCT04482933 }\end{array}$ & $\begin{array}{l}\text { Recruiting } \\
\text { Not yet } \\
\text { recruiting }\end{array}$ \\
\hline \multicolumn{8}{|l|}{ Measles Virus } \\
\hline MV-NIS & NIS insertion & $\begin{array}{l}\text { intraperitoneal and } \\
\text { Intratumoural }\end{array}$ & $|-| \mid$ & $\begin{array}{l}\text { Myeloma, Ovarian cancer, } \\
\text { Mesothelioma, NSCLC }\end{array}$ & $\begin{array}{l}\text { Combination or } \\
\text { OV only }\end{array}$ & $\begin{array}{l}\text { NCT02919449 } \\
\text { NCT02364713 }\end{array}$ & $\begin{array}{l}\text { Terminated } \\
\text { Recruiting }\end{array}$ \\
\hline MV-CEA & CEA insertion & $\begin{array}{l}\text { Intraperitoneal, } \\
\text { Intratumoural and } \\
\text { Intravenous }\end{array}$ & $|-| \mid$ & $\begin{array}{l}\text { Glioblastoma, Ovarian Cancer, } \\
\text { Fallopian Tube Endometrioid } \\
\text { Adenocarcinoma }\end{array}$ & OV only & $\begin{array}{l}\text { NCT00390299 } \\
\text { NCT00408590 } \\
\text { NCT02068794 }\end{array}$ & $\begin{array}{l}\text { Completed } \\
\text { Completed } \\
\text { Recruiting }\end{array}$ \\
\hline \multicolumn{8}{|l|}{ Vaccinia Virus } \\
\hline Pexa-vac (JX-594) & $\begin{array}{l}\text { GM-CSF insertion, } \\
\text { TK disruption }\end{array}$ & $\begin{array}{l}\text { Intratumoural and } \\
\text { Intravenous }\end{array}$ & $|-|||$ & $\begin{array}{l}\text { Melanoma, liver cancer, } \\
\text { colorectal cancer, breast cancer, } \\
\text { and hepatocellular carcinoma }\end{array}$ & $\begin{array}{l}\text { Combination or } \\
\text { OV only }\end{array}$ & $\begin{array}{l}\text { NCT02562755 } \\
\text { NCT00554372 } \\
\text { NCT00629759 }\end{array}$ & $\begin{array}{l}\text { Completed } \\
\text { Completed } \\
\text { Completed }\end{array}$ \\
\hline GL-ONC1 & $\begin{array}{l}\text { TK disruption, } \\
\text { haemagglutin } \\
\text { disruption, F14.5 L } \\
\text { disruption }\end{array}$ & $\begin{array}{l}\text { Intraperitoneal, } \\
\text { Intratumoural and } \\
\text { Intravenous }\end{array}$ & $|-| \mid$ & $\begin{array}{l}\text { Lung cancer, head and neck } \\
\text { cancer, and mesothelioma }\end{array}$ & $\begin{array}{l}\text { Combination or } \\
\text { OV only }\end{array}$ & $\begin{array}{l}\text { NCT02759588 } \\
\text { NCT01443260 }\end{array}$ & $\begin{array}{l}\text { Active } \\
\text { Completed }\end{array}$ \\
\hline \multicolumn{8}{|l|}{ Reovirus } \\
\hline Reolysin & None & Intravenous and & $|-|||$ & Glioma, sarcomas, colorectal & Combination or & NCT01166542 & Completed \\
\hline
\end{tabular}

Reovirus 
TABLE 2 | (Continued) Oncolytic virus anti-tumor clinical trials.

\begin{tabular}{|c|c|c|c|c|c|c|c|}
\hline Virus & Modification & $\begin{array}{c}\text { Virus } \\
\text { administration }\end{array}$ & Status & Indication & $\begin{array}{l}\text { Therapeutic } \\
\text { Approach }\end{array}$ & Clinical trials & Status \\
\hline \multicolumn{8}{|l|}{$\begin{array}{l}\text { Newcastle Disease } \\
\text { Virus }\end{array}$} \\
\hline PV701 & None & Intravenous & 1 & $\begin{array}{l}\text { Squamous Cell Carcinoma of the } \\
\text { Larynx, Salivary Gland Cancer }\end{array}$ & OV only & $\begin{array}{l}\text { NCT00081211 } \\
\text { NCT00055705 }\end{array}$ & $\begin{array}{l}\text { Terminated } \\
\text { Completed }\end{array}$ \\
\hline NDV-HUJ & None & Intravenous & $|-| \mid$ & $\begin{array}{l}\text { Glioblastoma, Sarcoma, } \\
\text { Neuroblastoma }\end{array}$ & OV only & NCT01174537 & Withdrawn \\
\hline \multicolumn{8}{|l|}{ Coxsackievirus } \\
\hline Cavatak (CVA21) & None & $\begin{array}{l}\text { Intravenous and } \\
\text { Intratumoural }\end{array}$ & $|-| \mid$ & $\begin{array}{l}\text { Bladder Cancer, NSCLC, Uveal } \\
\text { Melanoma, Breast Cancer, } \\
\text { Prostate Cancer, Head and Neck } \\
\text { Cancer }\end{array}$ & $\begin{array}{l}\text { Combination or } \\
\text { OV only }\end{array}$ & $\begin{array}{l}\text { NCT00636558 } \\
\text { NCT03408587 } \\
\text { NCT01636882 }\end{array}$ & $\begin{array}{l}\text { Completed } \\
\text { Completed } \\
\text { Complete }\end{array}$ \\
\hline \multicolumn{8}{|l|}{$\begin{array}{l}\text { Vesicular Stomatitis } \\
\text { Virus }\end{array}$} \\
\hline VSV-hIFN $\beta$ & IFN- $\beta$ insertion & Intratumoural & 1 & $\begin{array}{l}\text { Head and Neck Squamous Cell } \\
\text { Carcinoma, NSCLC, } \\
\text { Hepatocellular Carcinoma }\end{array}$ & Combination & $\begin{array}{l}\text { NCT02923466 } \\
\text { NCT01628640 }\end{array}$ & $\begin{array}{l}\text { Active } \\
\text { Active }\end{array}$ \\
\hline
\end{tabular}

of NSC-CRAd-S-pk7 in patients with high-grade glioma in a phase I clinical trial (Fares et al., 2021). Adenoviruses are also applied in celyvir, an advanced treatment that combines mesenchymal stem cells (MSCs) loaded with ICOVIR-5, an oncolytic adenovirus. David Ruano et al. demonstrated that MSCs ensure sufficient viral load by providing an immune shield to the virus in vitro (Ruano et al., 2020).

\subsubsection{Herpesviruses}

Herpesviruses are enveloped, icosahedral viruses containing double-stranded DNA, approximately $120-240 \mathrm{~kb}$. A total of more than 100 Herpesviruses have been found, which can be divided into three categories: $\alpha, \beta$, and $\gamma$ (Heldwein, 2018). Herpesviruses have demonstrated oncolytic properties in a variety of tumor types. T-VEC is an oncolytic virus derived from HSV-1 encoding GM-CSF. Robert H I Andtbacka et al. conducted a phase III clinical trial, which demonstrated that T-VEC has good and durable therapeutic effects in the treatment of advanced melanoma (Andtbacka et al., 2015). In 2015, T-VEC was approved by the United States FDA for the treatment of metastatic melanoma (Poh, 2016). T Mineta et al. created G207, a double mutant of the herpes simplex virus (HSV) type with deletion of ICP34.5 and insertional inactivation of UL39 (Mineta et al., 1995). Radiographic and neuropathological examinations have shown that G207 has antitumor activity and can be safely administered multiple times for the treatment of glioma (Markert et al., 2009). HF10 is a spontaneously mutated oncolytic virus derived from HSV1. Nakao et al. treated six breast cancer patients with HF10 (Nakao et al., 2007). Two superficial nodules were selected in all patients with metastatic breast cancer, one of which was injected with the virus directly and one of which served as a control. After treatment, none of the patients had obvious adverse reactions, and tumor cell death in the nodules was observed by histopathological methods.

\subsubsection{Measles Virus}

Measles virus is spherical or filamentous, with a diameter of about $120-250 \mathrm{~nm}$. The core inside is a single negative strand RNA, without segmentation, and the full length of the genome is about $16 \mathrm{~kb}$. Many studies have confirmed that MV has killing activity in prostate cancer, mesothelioma, ovarian cancer and other tumor cell lines (Hasegawa et al., 2006; Msaouel et al., 2009; Xia et al., 2019; Delaunay et al., 2020). Loi K Phuong et al. constructed MV-CEA, an MV that carries a gene encoding a carcinoembryonic antigen (Phuong et al., 2003). In a clinical trial, 21 patients with relapsed ovarian cancer received multiple intraperitoneal injections of MV-CEA within 4 weeks: 14 of them had stable disease (SD) after treatment, and five patients had decreased CA125 levels, which indicated that MV-CEA has good tumor-killing activity. Therefore, MV-CEA is a potentially effective antitumor drug.

\subsubsection{Vaccinia Virus}

Vaccinia virus is an enveloped virus. The genome of the vaccinia virus is made up of double stranded DNA of nearly $200 \mathrm{~kb}$ and replicates in the cytoplasm of the host cell (Greseth et al., 2012). Several genetically modified VV strains have been extensively tested in clinical trials (Guo et al., 2019). J H Kim et al. developed JX-594, a targeted, thymidine kinase (-) vaccinia virus expressing human GM-CSF. It can replicate in cancer cells and activate the body's antitumor immune response by expressing GM-CSF(Kim et al., 2006; Heo et al., 2013). A phase $1 \mathrm{~b}$ study showed that administration of JX-594 via intravenous infusion once every 2 weeks was safe and well tolerated (Park et al., 2015). A new phase $1 / 2$ study in early-stage tumors revealed that the combination of JX-594 and chemotherapy had a synergistic effect. However, the phase III study of JX-594/Sorafenib was terminated early. Combination therapy beyond Sorafenib monotherapy has yet failed to demonstrate superiority. Though it's a clinical failure for oncolytic virotherapy, 
Sorafenib was further shown to inhibit vaccinia virus replication in tumor cells, which indicates that JX-594 may not very suitable in the combination with Sorafenib (Gilchrist et al., 2020).

\subsubsection{Reoviruses}

Reoviruses are naked viruses with 10 segments of double-stranded DNA genomes. They are widely present in human respiratory and digestive tracts (Müller et al., 2020). Pelareorep, a serotype 3 reovirus, showed encouraging antitumor efficacy in combination with pembrolizumab in patients with advanced pancreatic adenocarcinoma (Mahalingam et al., 2020). Studies have shown that intratumoral injection and intravenous applications of reovirus are safe and tolerable (Samson et al., 2018). In clinical studies of intravenous injection of reovirus combined with administration of chemotherapeutics, such as carboplatin and paclitaxel, the patient survival period was significantly prolonged, and tumor progression has been inhibited (Kyula et al., 2012).

\subsubsection{Newcastle Disease Virus}

Newcastle disease virus is a ssRNA virus with an envelope. Virus particles are pleomorphic, including round, elliptical, and long rod-shaped. Since the Newcastle disease virus (NDV) was first discovered to replicate and kill tumor cells in 1955, researchers have investigated its potential as a tumor treatment (Hanson and Brandly, 1955; Wei et al., 2015). Due to tumor-specific defects in the IFN-mediated antiviral response, PV701, a natural attenuated virus, kills tumors selectively (Pecora et al., 2002). Seventy-nine patients with solid tumors were enrolled in a phase I clinical trial evaluating intravenously injected of PV701(Lorence et al., 2003). Among them, one patient with tonsil squamous cell carcinoma experienced tumor regression after treatment, and seven patients with different tumor types experienced tumor shrinkage. However, a patient with lung metastases died. The autopsy revealed severe inflammation in the lung tissue, which might have been related to the PV701 treatment.

\subsubsection{Coxsackieviruses}

Coxsackieviruses are non-enveloped viruses with single-stranded and positive polarity RNA genome and belong to the picornavirus family of the enterovirus genus (Kaese et al., 2017). Coxsackieviruses can be divided into two types, A and B. They are common viruses that infect the human body through the respiratory and digestive tracts. Coxsackievirus A21 (CVA21) is a naturally ICAM-1-targeted RNA virus (Müller et al., 2019). It can target ICAM-1-expressing tumor cells, leading to a systemic antitumor immune response. Phase I of the CVA21 study was conducted as part of an experimental treatment for bladder cancer, and the results confirmed that CVA21 is effective as an antitumor treatment by inducing immunogenic apoptosis in cancer cell lines (Annels et al., 2019).

\subsubsection{Vesicular Stomatitis Virus}

Vesicular Stomatitis Virus (VSV) is an enveloped, single-stranded negative sense RNA viruses of the family Rhabdoviridae (Nikolic et al., 2018). Two major serotypes of VSV have been identified, with representative strains named Indiana (VSIV) and New Jersey (VSNJV) strains (Velazquez-Salinas et al., 2017).
Vesicular stomatitis virus (VSV) can preferentially kill tumor cells with defective antiviral responses and has effective antitumor activity (Durham et al., 2017). Masatsugu Obuchi et al. genetically engineered VSV-hIFN $\beta$ that highly expresses the murine IFNbeta gene. While nonlytic against normal human cells, it easily kills tumor cells. Many clinical trials evaluating VSV-hIFN $\beta$ for different cancer types, such as head and neck cancer, lung cancer, melanoma, liver cancer, and endometrial cancer, are ongoing (Sterman et al., 2007; Willmon et al., 2009).

\subsubsection{Novel Nano-Pseudovirus}

Yingzhong $\mathrm{Li}$ et al. constructed a novel nano-pseudovirus that mimics the characteristics of oncolytic viruses that trigger immune responses in the body (Li et al., 2020). The nanopseudoviruses carry self-replicating RNA, which can activate the TLR3 signaling pathway, induce the body's immune response and promote the immunogenic cell death (ICD) of tumor cells. Preclinical research data show that $60-90 \%$ of melanoma and colon cancer lesions can be eliminated by one treatment with nanopseudovirus. The nano-pseudovirus can also effectively inhibit tumors in cases in which lung metastases have already formed. More clinical studies are needed in the future to verify the clinical safety and effectiveness of this approach.

\subsection{Combined Therapy}

The multifunctional characteristics of oncolytic viruses in the process of tumor treatment endow them with great potential for synergy when used in combination with other drugs. At present, substantial evidence indicates that oncolytic virus therapy can induce ICD when used in combination with radiotherapy, chemotherapy and other immunotherapies by enhancing tumor cell antigenicity or susceptibility to immune cells.

\subsubsection{Radiotherapy}

With the emergence of strategies combining oncolytic virus therapy with radiotherapy, the relationship between the two therapies has attracted the attention of researchers. The combination strategy has shown synergistic antitumor effects in various preclinical studies (Touchefeu et al., 2011; Mell et al., 2017). In some instances, radiotherapy could enhance oncolysis partly because it increases the virus replication rate. Radiotherapy promotes the upregulation of intracellular GADD34 expression, which can functionally replace $\gamma 34.5$, promote continuous protein synthesis, and increase the virus replication rate (Chou and Roizman, 1994; Kramm et al., 1997). After irradiation, the expression level of the coxsackie-adenovirus receptor (CAR) and/ or integrins increases, which leads to an increase in the uptake of the virus (Qian et al., 2005). As a radiation-inducing element, Egr-1 can enhance the expression of transgenes caused by radiation. TRAIL is an apoptosis-related gene (Oikonomou and Pintzas, 2013). Treatment of tumor cells with adenovirus expressing Egr-1/TRAIL combined with radiotherapy can induce high TRAIL expression levels. During this process, the expression of caspase 3 and caspase 8 can be increased, and their biological effects on apoptosis are also improved. These changes induce tumor regression and improve the survival time of tumor-bearing mice (Zhou et al., 2010; Wang et al., 2012). 


\subsubsection{Chemotherapy}

Chemotherapy is a common cancer treatment. However, tumor cells can develop resistance to chemotherapy drugs, often leading to chemotherapy failure. In recent years, some studies have proven that oncolytic viruses combined with chemotherapeutic drugs have significantly improved efficacy compared with the original single-drug treatment. When ONYX-015 is combined with the chemotherapeutic drugs cisplatin and 5-FU, the objective remission rate can reach $65 \%$, significantly higher than the $15 \%$ response rate of ONYX-015 alone (Khuri et al., 2000). Experimental data showed that combining the oncolytic virus H101 with chemotherapy can have antitumor effects by inducing cell cycle arrest in tumor cells (Cun et al., 2012). Combining vincristine (VCR) with oncolytic adenovirus SG600 slowed tumor growth by altering the cell cycle and reducing Akt phosphorylation (which normally induces chemotherapy resistance), thus increasing the sensitivity of the tumor cells to VCR. It was further confirmed that VCR does not affect the replication of SG600, ensuring oncolysis efficacy (Song et al., 2012).

\subsubsection{Targeted Therapies}

Targeted therapy inhibits the growth of tumor cells by acting on important tumorigenesis and development pathways. The combination of T-VEC and MEK inhibitors enhanced melanoma cell death in vitro, suppressed tumor growth and prolonged survival in mouse models (Bommareddy et al., 2018b). Combining si-Notch1 treatment with the oncolytic virus H101 did not affect viral replication and enhanced tumor cell apoptosis compared with the use of the single-agent therapy (Huang et al., 2012a; Yao et al., 2012). H101 combined with si-Bcl acts on the bax-p53 pathway, resulting in cell apoptosis and cell cycle arrest (Zhang et al., 2009; Huang et al., 2012b). GNAQ mutations are known to be associated with uveal melanoma (Jager et al., 2020). Combined therapy using si-GNAQ and H101 inhibits the proliferation of uveal melanoma cells by blocking the phosphorylation of mek $1 / 2$ and promoting the phosphorylation of yap (Li et al., 2019).

Immune checkpoint blockade (ICB) aims to resolve tumor escape by reversing tumor immunosuppressive signals. ICB cannot target tumors with low expression levels of immune checkpoint proteins; thus, no antitumor effects are observed in such tumors (Benci et al., 2016). When oncolytic viruses are used in combination with ICB drugs, the viruses can induce a large number of immune cells to infiltrate the tumor (Harrington et al., 2019). The tumor cells will further increase the expression level of checkpoint molecules, such as PD-L1 and CTLA-4, and induce the development of a selfprotection mechanism to escape immune attacks. Such combinations expand the scope of ICB drugs and enhance tumor sensitivity to ICB (Raja et al., 2018).

In a murine colon carcinoma model, the combination of a recombinant VV expressing CXCL11 and PD-L1 inhibitors was significantly more effective than monotherapy (Liu et al., 2017). In a phase I clinical study evaluating melanoma patients, combined treatment with T-VEC and the PD1 monoclonal antibody pembrolizumab yielded an objective response rate of
$62 \%$ among 21 patients, and the complete response rate was $33 \%$. In addition, the expression levels of PD-L1 and IFN- $\gamma$ were increased, and $\mathrm{T}$ cells infiltrated significantly into tumor tissues (Ribas et al., 2017).

\subsubsection{Adoptive T Cell Therapy}

Adoptive $\mathrm{T}$ cell therapy is a powerful strategy to augment $\mathrm{T}$ cell immune responses and improve antitumor capabilities (Restifo et al., 2012). Studies have revealed that oncolytic viruses enhance CAR-T cell recruitment by triggering antitumoral immunity (Wing et al., 2018). In a mouse neuroblastoma model, combined treatment with an oncolytic adenovirus (Ad5A24) expressing $\mathrm{CCl} 5$ and IL-15 and CAR-T cells targeting the tumor-associated ganglioside $\mathrm{gd} 2$ increased the overall survival period and survival rate of mice, and the function of CAR-T cells was strengthened (Nishio and Dotti, 2015). Recently, a new study reported that combined therapy with oncolytic viruses and CAR$\mathrm{T}$ cells can overcome the barriers of the tumor microenvironment and can successfully target and eradicate solid tumors that are otherwise difficult to treat with CAR-T cell therapy alone. In this study, researchers engineered the oncolytic virus to infect tumor cells and force tumor cell surface expression of CD19. Thus, the oncolytic efficacy of CD19-targeted CAR-T cells was enhanced (Park et al., 2020).

\section{DEFICIENCIES AND IMPROVEMENTS FOR ONCOLYTIC VIRUSES}

\subsection{Production}

The active replication properties of oncolytic viruses pose a unique challenge for monitoring and production. Most viruses multiply in tissues, and methods for high-titer virus production, foreign pathogen detection, viral purity determination and viral replication potential are required (Langfield et al., 2011). Such methods are costly, and existing technologies do not fully meet the requirements, limiting the large-scale production of oncolytic viruses. For some viruses, it is difficult to obtain the extremely high-titer lysate required for clinical doses; thus, oncolytic virus manufacturing is more challenging than the manufacturing of traditional biological products (Ungerechts et al., 2016). In addition, regulatory guidance and quality control systems for the manufacture of oncolytic viruses are not yet complete. It is necessary to consider safety issues related to production and amplification processes.

\subsection{Barriers}

Many factors determine the efficacy of oncolytic viruses in the body. There are some physical barriers in the body, such as macrophages, which can directly capture viruses in organs such as the liver, thereby reducing the viral titer in the body and affecting the oncolytic effect (Fulci et al., 2007; Yang et al., 2015). Macrophages are affected by clodronate; therefore, clodronate treatment may solve this problem (Denton et al., 2018). The use of appropriate cell carriers and liver off-target technology can also reduce the impact of macrophages on the virus (Power and Bell, 2008). 

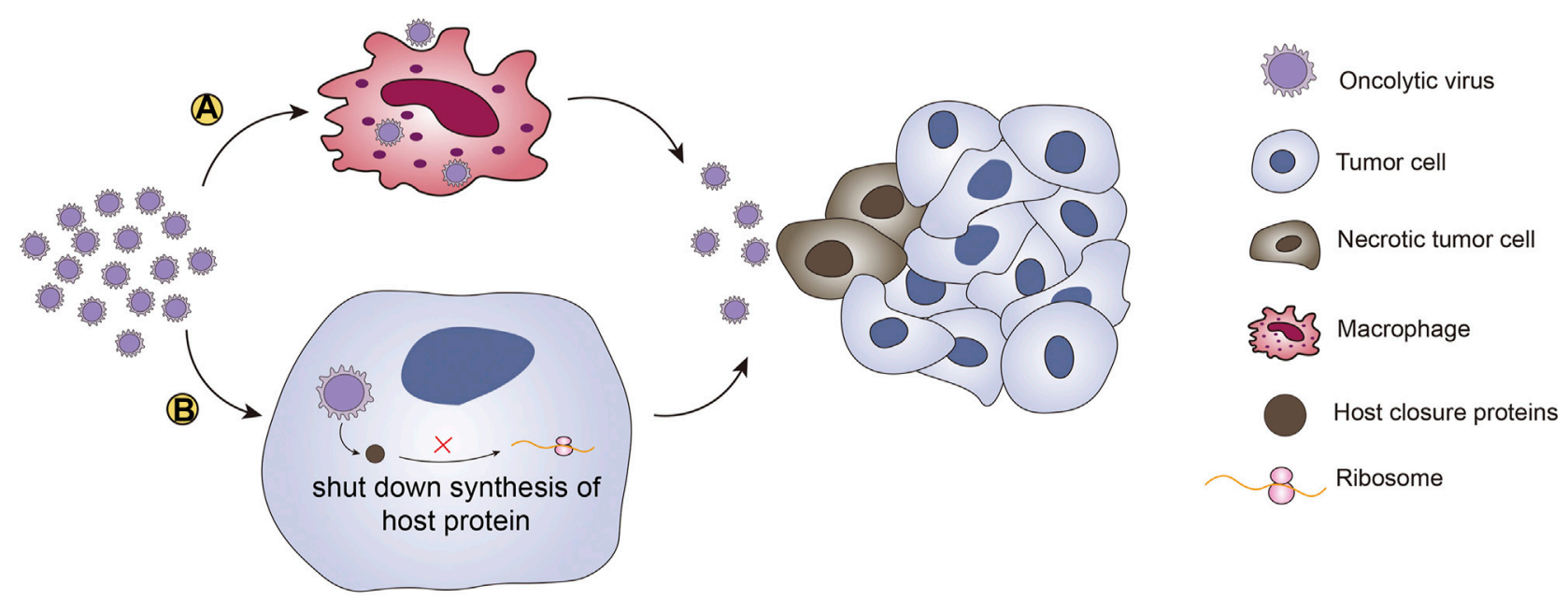

FIGURE 3 | Therapeutic barriers of oncolytic viruses. There are two main barriers to the induction of antitumor effects by oncolytic viruses. (A) Macrophages can directly capture viruses in organs such as the liver. Macrophages reduce the virus titer and the antitumor effects through phagocytosis. (B) The other barrier for oncolytic viruses is blockade of host protein synthesis. Oncolytic viruses encode host closure proteins that can shut down synthesis of host proteins, destroy pre-existing polysomes, degrade host mRNAs, and interfere with the production of viral offspring. This "host shutoff" is not conducive to virus replication or the expansion of neoantigen-reactive CTLs.

The body's immune barriers and antiviral responses can inhibit viral replication and lead to resistance to oncolytic viruses. Studies have shown that UL41 of HSV encodes host closure protein, which can shut down the synthesis of host proteins, destroy pre-existing polysomes, degrade host mRNA, and interfere with the production of viral offspring ( $\mathrm{Su}$ and Zheng, 2017). This blockade of host protein production is not conducive to the expansion of neoantigen-reactive CTLs. To avoid the restriction caused by the blockade of host protein production, it is better to choose viruses that have evolved to inhibit or shut down host cell protein synthesis when selecting oncolytic viruses. Genetic engineering can also be used to insert sequences into the viral genome that regulate biomolecules in the host protein synthesis pathways, thereby avoiding the impact of host protein shutdown on the oncolytic effect. After recognizing PRRs, the virus can promote the production of IFN1 and induce the inherent cellular antiviral response. Another method is the use of histone deacetylase inhibitors (HDIs), which are small molecules that were developed as anticancer agents (Gumbarewicz et al., 2016). HDIs can not only directly kill cancer cells but can also be combined with oncolytic viruses to reduce the antiviral immune response in the body. Nguyen et al. demonstrated that HDIs can enhance the activity of oncolytic viruses in multiple systems in vivo and in vitro (Nguyên et al., 2008) (Figure 3). However, safety is an important consideration when administering immunosuppressants, and systemic infectious diseases must be avoided.

\subsection{Safety}

The most common adverse events due to oncolytic viruses are low-grade systemic symptoms and local injection site reactions. Fever is the most common treatment-related adverse event, and the viruses can also cause chills, nausea and vomiting, flu-like symptoms, fatigue, and pain (Macedo et al., 2020). A recent clinical study showed that monotherapy and combined therapy with G207 significantly improve the prognosis of pediatric high-grade gliomas, with good safety and tolerability, which indicates that oncolytic viruses are not only safe and effective for adults, but also show good tolerance in children (Friedman et al., 2021). Generally, the safety of oncolytic viruses is acceptable. However, oncolytic viruses are not entirely safe, and some safety problems urgently need to be solved. Although genetically engineered oncolytic viruses have increased targeting and decreased toxicity, they still have offtarget and unexpected toxic effects (Buijs et al., 2015). Qiao et al. observed that the use of cyclophosphamide to suppress the immune response and the ablation of neutralizing antibodies can lead to severe reovirus toxicity (Qiao et al., 2008). The oncolytic virus VSV has been shown to have low targeting ability and is mainly found in large numbers in normal tissues. In IFN- $\alpha / \beta$ knockout mice, VSV can exhibit severe toxicity. Such experiments have proven that although the immune system may reduce the antitumor effect of oncolytic viruses, it also plays an important role in limiting the virus and maintaining safety. Researchers are continuously making efforts to improve tumor targeting and virus potency. To improve tumor targeting ability, sequences of differentially expressed microRNAs are integrated into OVs, which can be adapted to various viruses and reduce damage to healthy cells (Ruiz and Russell, 2015). Ad (CgA-E1A-miR122) was constructed using miR-122 to regulate E1A expression, ensuring selective replication in tumors. Studies have shown that this combination of transcriptional and posttranscriptional regulation allows higher doses of adenovirus for antitumor treatment without liver toxicity (Leja et al., 2010). 


\section{DISCUSSION}

Oncolytic viruses are natural or genetically modified viruses that can selectively replicate in tumor cells and have long been recognized for their ability to kill cancer cells. Many years of research have shed light on the mechanism by which oncolytic viruses kill tumors. Oncolytic viruses not only kill tumor cells directly through virus replication but also convert cold tumors into hot tumors by regulating the release of immune-related molecules, enhancing the immunogenicity of tumors, and promoting the maturation, migration and infiltration of immune cells, thereby improving the antitumor immune response. In addition, oncolytic viruses can affect the neovascularization of tumors and inhibit tumor growth. The effectiveness of the oncolytic virus depends on the oncolytic virus infecting tumor cells in a sufficient number. The doseresponse relationship of OVs cannot be predicted easily and varies across different methods of delivery (Peng et al., 2006). As the best route of administration is still uncertain, it is essential to explore suitable routes. The most common route of $\mathrm{OV}$ administration is intratumoral injection. This approach has advantages in avoiding hemodilution and the anti-vector immunity response. It can also decrease the risk for off-target side effects. However, this method has some deficiencies. Intratumoral administration is associated with a risk for deep tissue injuries and bleeding in some tumors, such as intracranial tumors and malignancies near the edge of the liver. Meanwhile, the lack of secondary viremia may result in limited immune activity (Andtbacka et al., 2016). The advantage of intravenous delivery is that multiple sites (including metastasis sites) can be targeted regardless of tumor location; additionally, the therapy is easy to administer (Bommareddy et al., 2018a). However, hemodilution is a limiting factor (Breitbach et al., 2011). The tumor is not accessible when it comes to isolation in non-target organs or the inability of the virus to extravasate through the vasculature (Ferguson et al., 2012). There are other routes of administration for specific types of tumor, such as intraperitoneal delivery for digestive tract malignancy (Kulu et al., 2009), isolated limb perfusion for extremity sarcoma (Pencavel et al., 2015) and aerosol delivery for lung tumors

\section{REFERENCES}

Alessandrini, F., Menotti, L., Avitabile, E., Appolloni, I., Ceresa, D., Marubbi, D., et al. (2019). Eradication of Glioblastoma by Immuno-Virotherapy with a Retargeted Oncolytic HSV in a Preclinical Model. Oncogene 38 (23), 4467-4479. doi:10.1038/s41388-019-0737-2

Andtbacka, R. H. I., Kaufman, H. L., Collichio, F., Amatruda, T., Senzer, N., Chesney, J., et al. (2015). Talimogene Laherparepvec Improves Durable Response Rate in Patients with Advanced Melanoma. Jco 33 (25), 2780-2788. doi:10.1200/jco.2014.58.3377

Andtbacka, R. H. I., Ross, M., Puzanov, I., Milhem, M., Collichio, F., Delman, K. A., et al. (2016). Patterns of Clinical Response with Talimogene Laherparepvec (T-VEC) in Patients with Melanoma Treated in the OPTiM Phase III Clinical Trial. Ann. Surg. Oncol. 23 (13), 4169-4177. doi:10.1245/s10434-016-5286-0

Annels, N. E., Mansfield, D., Arif, M., Ballesteros-Merino, C., Simpson, G. R., Denyer, M., et al. (2019). Phase I Trial of an ICAM-1-Targeted Immunotherapeutic-Coxsackievirus A21 (CVA21) as an Oncolytic Agent
(Hong et al., 2015). Developing suitable drug delivery systems is an important direction for oncolytic virus research. Recently, many clinical trials evaluating oncolytic viruses have been carried out, involving different types of viruses and tumors. Treatment methods also vary from single-drug therapies to multidrug combination therapies. Most trials have achieved good results. Although oncolytic viruses have immeasurable application potential and can be marketed as therapeutic agents, some barriers exist to their production and application. Current molecular biotechnology strategies have enhanced the targeting and killing effects of oncolytic viruses; however, to develop tumor treatment methods with higher curative effects and lower adverse reaction rates, further development is needed. Additionally, because the production technology used to generate oncolytic viruses is not perfect, and there is no unified standard for the supervision and quality inspection of industrial production, there are still barriers to the large-scale production and application of oncolytic viruses. Therefore, more extensive research on oncolytic viruses is needed in the future to develop more optimized treatments.

\section{AUTHOR CONTRIBUTIONS}

XF and SG designed the structure of this review. LY, XG, and JY performed the literature searches and contributed to draft versions of the manuscript. LY wrote and revised the final version of the manuscript. All authors contributed to the article and approved the submitted version.

\section{FUNDING}

This work was supported by the National Key Research and Development Plan (2017YFE0196300), the National Natural Science Foundation of China (Nos. 81772875, U1932135, 82073889), the Clinical Research Plan of SHDC (SHDC2020CR1009A), the Science and Technology Commission of Shanghai (20DZ2270800 and 19JC1410200).

against Non Muscle-Invasive Bladder Cancer. Clin. Cancer Res. 25 (19), 5818-5831. doi:10.1158/1078-0432.ccr-18-4022

Axelrod, M. L., Cook, R. S., Johnson, D. B., and Balko, J. M. (2019). Biological Consequences of MHC-II Expression by Tumor Cells in Cancer. Clin. Cancer Res. 25 (8), 2392-2402. doi:10.1158/1078-0432.ccr-18-3200

Barker, D. D., and Berk, A. J. (1987). Adenovirus Proteins from Both E1B reading Frames Are Required for Transformation of Rodent Cells by Viral Infection and DNA Transfection. Virology 156 (1), 107-121. doi:10.1016/0042-6822(87) 90441-7

Benci, J. L., Xu, B., Qiu, Y., Wu, T. J., Dada, H., Twyman-Saint Victor, C., et al. (2016). Tumor Interferon Signaling Regulates a Multigenic Resistance Program to Immune Checkpoint Blockade. Cell 167 (6), 1540-1554.e12. doi:10.1016/ j.cell.2016.11.022

Bischoff, J. R., Kirn, D. H., Williams, A., Heise, C., Horn, S., Muna, M., et al. (1996). An Adenovirus Mutant that Replicates Selectively in P53- Deficient Human Tumor Cells. Science 274 (5286), 373-376. doi:10.1126/science.274.5286.373

Boivin, G., Abed, Y., Pelletier, G., Ruel, L., Moisan, D., Côté, S., et al. (2002). Virological Features and Clinical Manifestations Associated with Human 
Metapneumovirus: A New Paramyxovirus Responsible for Acute RespiratoryTract Infections in All Age Groups. J. Infect. Dis. 186 (9), 1330-1334. doi: $10.1086 / 344319$

Bommareddy, P. K., Aspromonte, S., Zloza, A., Rabkin, S. D., and Kaufman, H. L. (2018). MEK Inhibition Enhances Oncolytic Virus Immunotherapy through Increased Tumor Cell Killing and T Cell Activation. Sci. Transl Med. 10 (471), eaau0417. doi:10.1126/scitranslmed.aau0417

Bommareddy, P. K., Shettigar, M., and Kaufman, H. L. (2018). Integrating Oncolytic Viruses in Combination Cancer Immunotherapy. Nat. Rev. Immunol. 18 (8), 498-513. doi:10.1038/s41577-018-0014-6

Borsig, L. (2018). Selectins in Cancer Immunity. Glycobiology 28 (9), 648-655. doi:10.1093/glycob/cwx105

Bourgeois-Daigneault, M.-C., Roy, D. G., Falls, T., Twumasi-Boateng, K., StGermain, L. E., Marguerie, M., et al. (2016). Oncolytic Vesicular Stomatitis Virus Expressing Interferon- $\sigma$ Has Enhanced Therapeutic Activity. Mol. Ther. Oncolytics 3, 16001. doi:10.1038/mto.2016.1

Breitbach, C. J., Arulanandam, R., De Silva, N., Thorne, S. H., Patt, R., Daneshmand, M., et al. (2013). Oncolytic Vaccinia Virus Disrupts TumorAssociated Vasculature in Humans. Cancer Res. 73 (4), 1265-1275. doi:10.1158/0008-5472.can-12-2687

Breitbach, C. J., Burke, J., Jonker, D., Stephenson, J., Haas, A. R., Chow, L. Q. M., et al. (2011). Intravenous Delivery of a Multi-Mechanistic Cancer-Targeted Oncolytic Poxvirus in Humans. Nature 477 (7362), 99-102. doi:10.1038/ nature10358

Breitbach, C. J., Paterson, J. M., Lemay, C. G., Falls, T. J., McGuire, A., Parato, K. A., et al. (2007). Targeted Inflammation during Oncolytic Virus Therapy Severely Compromises Tumor Blood Flow. Mol. Ther. 15 (9), 1686-1693. doi:10.1038/ sj.mt.6300215

Buijs, P. R., Verhagen, J. H., van Eijck, C. H., and van den Hoogen, B. G. (2015). Oncolytic Viruses: From Bench to Bedside with a Focus on Safety. Hum. Vaccin. Immunother. 11 (7), 1573-1584. doi:10.1080/ 21645515.2015.1037058

Callegari, E., Elamin, B. K., D’Abundo, L., Falzoni, S., Donvito, G., Moshiri, F., et al. (2013). Anti-tumor Activity of a miR-199-dependent Oncolytic Adenovirus. PLoS One 8 (9), e73964. doi:10.1371/journal.pone.0073964

Carew, J. S., Espitia, C. M., Zhao, W., Mita, M. M., Mita, A. C., and Nawrocki, S. T. (2017). Oncolytic Reovirus Inhibits Angiogenesis through Induction of CXCL10/IP-10 and Abrogation of HIF Activity in Soft Tissue Sarcomas. Oncotarget 8 (49), 86769-86783. doi:10.18632/ oncotarget.21423

Chen, X., Liu, S., Goraya, M. U., Maarouf, M., Huang, S., and Chen, J.-L. (2018). Host Immune Response to Influenza A Virus Infection. Front. Immunol. 9, 320. doi:10.3389/fimmu.2018.00320

Cheng, P.-H., Rao, X.-M., Duan, X., Li, X.-F., Egger, M. E., McMasters, K. M., et al. (2015). Virotherapy Targeting Cyclin E Overexpression in Tumors with Adenovirus-Enhanced Cancer-Selective Promoter. J. Mol. Med. 93 (2), 211-223. doi:10.1007/s00109-014-1214-6

Chon, H. J., Lee, W. S., Yang, H., Kong, S. J., Lee, N. K., Moon, E. S., et al. (2019). Tumor Microenvironment Remodeling by Intratumoral Oncolytic Vaccinia Virus Enhances the Efficacy of Immune-Checkpoint Blockade. Clin. Cancer Res. 25 (5), 1612-1623. doi:10.1158/1078-0432.CCR-18-1932

Chou, J., and Roizman, B. (1994). Herpes Simplex Virus 1 gamma(1)34.5 Gene Function, Which Blocks the Host Response to Infection, Maps in the Homologous Domain of the Genes Expressed during Growth Arrest and DNA Damage. Proc. Natl. Acad. Sci. 91 (12), 5247-5251. doi:10.1073/ pnas.91.12.5247

Conrad, S. J., El-Aswad, M., Kurban, E., Jeng, D., Tripp, B. C., Nutting, C., et al. (2015). Oncolytic Tanapoxvirus Expressing FliC Causes Regression of Human Colorectal Cancer Xenografts in Nude Mice. J. Exp. Clin. Cancer Res. 34 (1), 19. doi:10.1186/s13046-015-0131-z

Cun, B., Song, X., Jia, R., Zhao, X., Wang, H., Ge, S., et al. (2012). Combination of Oncolytic Adenovirus and Dacarbazine Enhances Antitumor Ability against Uveal Melanoma Cells via Cell Cycle Block. Cancer Biol. Ther. 13 (2), 77-84. doi:10.4161/cbt.13.2.18436

Delaunay, T., Achard, C., Boisgerault, N., Grard, M., Petithomme, T., Chatelain, C., et al. (2020). Frequent Homozygous Deletions of Type I Interferon Genes in Pleural Mesothelioma Confer Sensitivity to Oncolytic Measles Virus. J. Thorac. Oncol. 15 (5), 827-842. doi:10.1016/j.jtho.2019.12.128
Deng, L., Fan, J., Guo, M., and Huang, B. (2016). Oncolytic and Immunologic Cancer Therapy with GM-CSF-Armed Vaccinia Virus of Tian Tan Strain Guang9. Cancer Lett. 372 (2), 251-257. doi:10.1016/j.canlet.2016.01.025

Denton, N. L., Chen, C.-Y., Hutzen, B., Currier, M. A., Scott, T., Nartker, B., et al. (2018). Myelolytic Treatments Enhance Oncolytic Herpes Virotherapy in Models of Ewing Sarcoma by Modulating the Immune Microenvironment. Mol. Ther. - Oncolytics 11, 62-74. doi:10.1016/j.omto.2018.10.001

Deweese, T. L., van der Poel, H., Li, S., Mikhak, B., Drew, R., Goemann, M., et al. (2001). A Phase I Trial of CV706, a Replication-Competent, PSA Selective Oncolytic Adenovirus, for the Treatment of Locally Recurrent Prostate Cancer Following Radiation Therapy. Cancer Res. 61 (20), 7464-7472.

Dias, J. D., Liikanen, I., Guse, K., Foloppe, J., Sloniecka, M., Diaconu, I., et al. (2010). Targeted Chemotherapy for Head and Neck Cancer with a Chimeric Oncolytic Adenovirus Coding for Bifunctional Suicide Protein FCU1. Clin. Cancer Res. 16 (9), 2540-2549. doi:10.1158/1078-0432.ccr-09-2974

Dix, B. R., O'Carroll, S. J., Myers, C. J., Edwards, S. J., and Braithwaite, A. W. (2000). Efficient Induction of Cell Death by Adenoviruses Requires Binding of E1B55k and P53. Cancer Res. 60 (10), 2666-2672.

Durham, N. M., Mulgrew, K., McGlinchey, K., Monks, N. R., Ji, H., Herbst, R., et al. (2017). Oncolytic VSV Primes Differential Responses to Immuno-Oncology Therapy. Mol. Ther. 25 (8), 1917-1932. doi:10.1016/j.ymthe.2017.05.006

Edukulla, R., Ramakrishna, E., Woller, N., Mundt, B., Knocke, S., Gürlevik, E., et al. (2009). Antitumoral Immune Response by Recruitment and Expansion of Dendritic Cells in Tumors Infected with Telomerase-dependent Oncolytic Viruses. Cancer Res. 69 (4), 1448-1458. doi:10.1158/0008-5472.CAN-08-1160

Fares, J., Ahmed, A. U., Ulasov, I. V., Sonabend, A. M., Miska, J., Lee-Chang, C., et al. (2021). Neural Stem Cell Delivery of an Oncolytic Adenovirus in Newly Diagnosed Malignant Glioma: a First-In-Human, Phase 1, Dose-Escalation Trial. Lancet Oncol. 22, 1103-1114. doi:10.1016/s1470-2045(21)00245-x

Ferguson, M. S., Lemoine, N. R., and Wang, Y. (2012). Systemic Delivery of Oncolytic Viruses: Hopes and Hurdles. Adv. Virol. 2012, 805629. doi:10.1155/ 2012/805629

Foloppe, J., Kempf, J., Futin, N., Kintz, J., Cordier, P., Pichon, C., et al. (2019). The Enhanced Tumor Specificity of TG6002, an Armed Oncolytic Vaccinia Virus Deleted in Two Genes Involved in Nucleotide Metabolism. Mol. Ther. Oncolytics 14, 1-14. doi:10.1016/j.omto.2019.03.005

Friedman, G. K., Johnston, J. M., Bag, A. K., Bernstock, J. D., Li, R., Aban, I., et al. (2021). Oncolytic HSV-1 G207 Immunovirotherapy for Pediatric High-Grade Gliomas. N. Engl. J. Med. 384 (17), 1613-1622. doi:10.1056/nejmoa2024947

Fulci, G., Dmitrieva, N., Gianni, D., Fontana, E. J., Pan, X., Lu, Y., et al. (2007). Depletion of Peripheral Macrophages and Brain Microglia Increases Brain Tumor Titers of Oncolytic Viruses. Cancer Res. 67 (19), 9398-9406. doi:10.1158/0008-5472.can-07-1063

Galon, J., and Bruni, D. (2019). Approaches to Treat Immune Hot, Altered and Cold Tumours with Combination Immunotherapies. Nat. Rev. Drug Discov. 18 (3), 197-218. doi:10.1038/s41573-018-0007-y

Gholami, S., Marano, A., Chen, N. G., Aguilar, R. J., Frentzen, A., Chen, C.-H., et al. (2016). Erratum to: A Novel Vaccinia Virus with Dual Oncolytic and Antiangiogenic Therapeutic Effects against Triple-Negative Breast Cancer. Breast Cancer Res. Treat. 156 (3), 607-608. doi:10.1007/s10549-016-3767-2

Gilchrist, V. H., Jémus-Gonzalez, E., Said, A., and Alain, T. (2020). Kinase Inhibitors with Viral Oncolysis: Unmasking Pharmacoviral Approaches for Cancer Therapy. Cytokine Growth Factor. Rev. 56, 83-93. doi:10.1016/ j.cytogfr.2020.07.008

Gonzalez, N. R., Liou, R., Kurth, F., Jiang, H., and Saver, J. (2018). Antiangiogenesis and Medical Therapy Failure in Intracranial Atherosclerosis. Angiogenesis 21 (1), 23-35. doi:10.1007/s10456-017-9578-1

Greber, U. F., and Flatt, J. W. (2019). Adenovirus Entry: From Infection to Immunity. Annu. Rev. Virol. 6 (1), 177-197. doi:10.1146/annurev-virology092818-015550

Greseth, M. D., Boyle, K. A., Bluma, M. S., Unger, B., Wiebe, M. S., Soares-Martins, J. A., et al. (2012). Molecular Genetic and Biochemical Characterization of the Vaccinia Virus I3 Protein, the Replicative Single-Stranded DNA Binding Protein. J. Virol. 86 (11), 6197-6209. doi:10.1128/jvi.00206-12

Guerra, P., Valbuena, A., Querol-Audí, J., Silva, C., Castellanos, M., RodríguezHuete, A., et al. (2017). Structural Basis for Biologically Relevant Mechanical Stiffening of a Virus Capsid by Cavity-Creating or Spacefilling Mutations. Sci. Rep. 7 (1), 4101. doi:10.1038/s41598-017-04345-w 
Gumbarewicz, E., Luszczki, J. J., Wawruszak, A., Dmoszynska-Graniczka, M., Grabarska, A. J., Jarząb, A. M., et al. (2016). Isobolographic Analysis Demonstrates Additive Effect of Cisplatin and HDIs Combined Treatment Augmenting Their Anti-cancer Activity in Lung Cancer Cell Lines. Am. J. Cancer Res. 6 (12), 2831-2845.

Guo, Z. S., Lu, B., Guo, Z., Giehl, E., Feist, M., Dai, E., et al. (2019). Vaccinia VirusMediated Cancer Immunotherapy: Cancer Vaccines and Oncolytics. J. Immunotherapy Cancer 7 (1), 6. doi:10.1186/s40425-018-0495-7

Hanson, R. P., and Brandly, C. A. (1955). Identification of Vaccine Strains of Newcastle Disease Virus. Science 122 (3160), 156-157. doi:10.1126/ science.122.3160.156-b

Harrington, K., Freeman, D. J., Kelly, B., Harper, J., and Soria, J.-C. (2019). Optimizing Oncolytic Virotherapy in Cancer Treatment. Nat. Rev. Drug Discov. 18 (9), 689-706. doi:10.1038/s41573-019-0029-0

Hasegawa, K., Nakamura, T., Harvey, M., Ikeda, Y., Oberg, A., Figini, M., et al. (2006). The Use of a Tropism-Modified Measles Virus in Folate ReceptorTargeted Virotherapy of Ovarian Cancer. Clin. Cancer Res. 12 (20 Pt 1), 6170-6178. doi:10.1158/1078-0432.CCR-06-0992

Havunen, R., Siurala, M., Sorsa, S., Vähä-Koskela, S. G., Behr, M., Tähtinen, S., et al. (2017). Oncolytic Adenoviruses Armed with Tumor Necrosis Factor Alpha and Interleukin-2 Enable Successful Adoptive Cell Therapy. Mol. Ther. Oncolytics 4, 77-86. doi:10.1016/j.omto.2016.12.004

Heldwein, E. E. (2018). Up Close with Herpesviruses. Science 360 (6384), 34-35. doi:10.1126/science.aat3990

Heo, J., Reid, T., Ruo, L., Breitbach, C. J., Rose, S., Bloomston, M., et al. (2013). Randomized Dose-Finding Clinical Trial of Oncolytic Immunotherapeutic Vaccinia JX-594 in Liver Cancer. Nat. Med. 19 (3), 329-336. doi:10.1038/nm.3089

Hirvinen, M., Rajecki, M., Kapanen, M., Parviainen, S., Rouvinen-Lagerström, N., Diaconu, I., et al. (2015). Immunological Effects of a Tumor Necrosis Factor Alpha-Armed Oncolytic Adenovirus. Hum. Gene Ther. 26 (3), 134-144. doi:10.1089/hum.2014.069

Hong, S.-H., Park, S.-J., Lee, S., Cho, C. S., and Cho, M.-H. (2015). Aerosol Gene Delivery Using Viral Vectors and Cationic Carriers Forin Vivolung Cancer Therapy. Expert Opin. Drug Deliv. 12 (6), 977-991. doi:10.1517/ 17425247.2015 .986454

Huang, X., Jia, R., Zhao, X., Liu, B., Wang, H., Wang, J., et al. (2012). Recombinant Oncolytic Adenovirus H101 Combined with siBCL2: Cytotoxic Effect on Uveal Melanoma Cell Lines. Br. J. Ophthalmol. 96 (10), 1331-1338. doi:10.1136/ bjophthalmol-2011-301470

Huang, X., Wang, L., Zhang, H., Wang, H., Zhao, X., Qian, G., et al. (2012). Therapeutic Efficacy by Targeting Correction of Notch1-Induced Aberrants in Uveal Tumors. PLoS One 7 (8), e44301. doi:10.1371/journal.pone.0044301

Husseini, F., Delord, J.-P., Fournel-Federico, C., Guitton, J., Erbs, P., Homerin, M., et al. (2017). Vectorized Gene Therapy of Liver Tumors: Proof-Of-Concept of TG4023 (MVA-FCU1) in Combination with Flucytosine. Ann. Oncol. 28 (1), 169-174. doi:10.1093/annonc/mdw440

Hutzen, B., Bid, H. K., Houghton, P. J., Pierson, C. R., Powell, K., Bratasz, A., et al. (2014). Treatment of Medulloblastoma with Oncolytic Measles Viruses Expressing the Angiogenesis Inhibitors Endostatin and Angiostatin. BMC Cancer 14, 206. doi:10.1186/1471-2407-14-206

Ilkow, C. S., Swift, S. L., Bell, J. C., and Diallo, J.-S. (2014). From Scourge to Cure: Tumour-Selective Viral Pathogenesis as a New Strategy against Cancer. Plos Pathog. 10 (1), e1003836. doi:10.1371/journal.ppat.1003836

Indraccolo, S., Gola, E., Rosato, A., Minuzzo, S., Habeler, W., Tisato, V., et al. (2002). Differential Effects of Angiostatin, Endostatin and Interferon-A1 Gene Transfer on In Vivo Growth of Human Breast Cancer Cells. Gene Ther. 9 (13), 867-878. doi:10.1038/sj.gt.3301703

Jager, M. J., Shields, C. L., Cebulla, C. M., Abdel-Rahman, M. H., Grossniklaus, H. E., Stern, M.-H., et al. (2020). Uveal Melanoma. Nat. Rev. Dis. Primers 6 (1), 24. doi:10.1038/s41572-020-0158-0

Jennings, V. A., Scott, G. B., Rose, A. M. S., Scott, K. J., Migneco, G., Keller, B., et al. (2019). Potentiating Oncolytic Virus-Induced Immune-Mediated Tumor Cell Killing Using Histone Deacetylase Inhibition. Mol. Ther. 27 (6), 1139-1152. doi:10.1016/j.ymthe.2019.04.008

Jing, Y., Zaias, J., Duncan, R., Russell, S. J., and Merchan, J. R. (2014). In Vivo safety, Biodistribution and Antitumor Effects of uPAR Retargeted Oncolytic Measles Virus in Syngeneic Cancer Models. Gene Ther. 21 (3), 289-297. doi:10.1038/ gt.2013.84
Kaese, S., Larbig, R., Rohrbeck, M., Frommeyer, G., Dechering, D., Olligs, J., et al. (2017). Electrophysiological Alterations in a Murine Model of Chronic Coxsackievirus B3 Myocarditis. PLoS One 12 (6), e0180029. doi:10.1371/ journal.pone.0180029

Karjoo, Z., Chen, X., and Hatefi, A. (2016). Progress and Problems with the Use of Suicide Genes for Targeted Cancer Therapy. Adv. Drug Deliv. Rev. 99 (Pt A), 113-128. doi:10.1016/j.addr.2015.05.009

Kato, K., Omura, H., Ishitani, R., and Nureki, O. (2017). Cyclic GMP-AMP as an Endogenous Second Messenger in Innate Immune Signaling by Cytosolic DNA. Аnпu. Rev. Biochem. 86, 541-566. doi:10.1146/annurev-biochem-061516044813

Kaufman, H. L., Kohlhapp, F. J., and Zloza, A. (2016). Erratum: Oncolytic Viruses: a New Class of Immunotherapy Drugs. Nat. Rev. Drug Discov. 15 (9), 660. doi:10.1038/nrd.2016.178

Khattar, S. K., Samal, S., DeVico, A. L., Collins, P. L., and Samal, S. K. (2011). Newcastle Disease Virus Expressing Human Immunodeficiency Virus Type 1 Envelope Glycoprotein Induces strong Mucosal and Serum Antibody Responses in Guinea Pigs. J. Virol. 85 (20), 10529-10541. doi:10.1128/ jvi.05050-11

Khuri, F. R., Nemunaitis, J., Ganly, I., Arseneau, J., Tannock, I. F., Romel, L., et al. (2000). A Controlled Trial of Intratumoral ONYX-015, a SelectivelyReplicating Adenovirus, in Combination with Cisplatin and 5-fluorouracil in Patients with Recurrent Head and Neck Cancer. Nat. Med. 6 (8), 879-885. doi:10.1038/78638

Kim, J. H., Oh, J. Y., Park, B. H., Lee, D. E., Kim, J. S., Park, H. E., et al. (2006). Systemic Armed Oncolytic and Immunologic Therapy for Cancer with JX-594, a Targeted Poxvirus Expressing GM-CSF. Mol. Ther. 14 (3), 361-370. doi:10.1016/j.ymthe.2006.05.008

Kramm, C. M., Chase, M., Herrlinger, U., Jacobs, A., Pechan, P. A., Rainov, N. G., et al. (1997). Therapeutic Efficiency and Safety of a Second-Generation Replication-Conditional HSV1 Vector for Brain Tumor Gene Therapy. Hum. Gene Ther. 8 (17), 2057-2068. doi:10.1089/hum.1997.8.17-2057

Kulu, Y., Dorfman, J. D., Kuruppu, D., Fuchs, B. C., Goodwin, J. M., Fujii, T., et al. (2009). Comparison of Intravenous versus Intraperitoneal Administration of Oncolytic Herpes Simplex Virus 1 for Peritoneal Carcinomatosis in Mice. Cancer Gene Ther. 16 (4), 291-297. doi:10.1038/cgt.2008.83

Sato, D., Kurihara, Y., Konda, S., Shirota, T., Urata, Y., Fujiwara, T., et al. (2013). Antitumor Effects of Telomerase-specific Replication-Selective Oncolytic Viruses for Adenoid Cystic Carcinoma Cell Lines. Oncol. Rep. 30 (6), 2659-2664. doi:10.3892/or.2013.2738

Kurokawa, C., Iankov, I. D., Anderson, S. K., Aderca, I., Leontovich, A. A., Maurer, M. J., et al. (2018). Constitutive Interferon Pathway Activation in Tumors as an Efficacy Determinant Following Oncolytic Virotherapy. J. Natl. Cancer Inst. 110 (10), 1123-1132. doi:10.1093/jnci/djy033

Kyula, J. N., Roulstone, V., Karapanagiotou, E. M., Melcher, A. A., and Harrington, K. J. (2012). Oncolytic Reovirus Type 3 (Dearing) as a Novel Therapy in Head and Neck Cancer. Expert Opin. Biol. Ther. 12 (12), 1669-1678. doi:10.1517/ 14712598.2012.745507

Langfield, K. K., Walker, H. J., Gregory, L. C., and Federspiel, M. J. (2011). Manufacture of Measles Viruses. Methods Mol. Biol. 737, 345-366. doi:10.1007/ 978-1-61779-095-9_14

Lawler, S. E., Speranza, M.-C., Cho, C.-F., and Chiocca, E. A. (2017). Oncolytic Viruses in Cancer Treatment. JAMA Oncol. 3 (6), 841-849. doi:10.1001/ jamaoncol.2016.2064

Lee, C. S., Bishop, E. S., Zhang, R., Yu, X., Farina, E. M., Yan, S., et al. (2017). Adenovirus-mediated Gene Delivery: Potential Applications for Gene and CellBased Therapies in the new era of Personalized Medicine. Genes Dis. 4 (2), 43-63. doi:10.1016/j.gendis.2017.04.001

Leja, J., Nilsson, B., Yu, D., Gustafson, E., Åkerström, G., Öberg, K., et al. (2010). Double-detargeted Oncolytic Adenovirus Shows Replication Arrest in Liver Cells and Retains Neuroendocrine Cell Killing Ability. PLoS One 5 (1), e8916. doi:10.1371/journal.pone.0008916

Li, Y., He, J., Qiu, C., Shang, Q., Qian, G., Fan, X., et al. (2019). The Oncolytic Virus H101 Combined with GNAQ siRNA-mediated Knockdown Reduces Uveal Melanoma Cell Viability. J. Cell Biochem 120 (4), 5766-5776. doi:10.1002/ jcb. 27863

Li, Y., Hong, J., Oh, J.-E., Yoon, A.-R., and Yun, C.-O. (2018). Potent Antitumor Effect of Tumor Microenvironment-Targeted Oncolytic Adenovirus against 
Desmoplastic Pancreatic Cancer. Int. J. Cancer 142 (2), 392-413. doi:10.1002/ ijc.31060

Li, Y., Su, Z., Zhao, W., Zhang, X., Momin, N., Zhang, C., et al. (2020). Multifunctional Oncolytic Nanoparticles Deliver Self-Replicating IL-12 RNA to Eliminate Established Tumors and Prime Systemic Immunity. Nat. Cancer 1, 882-893. doi:10.1038/s43018-020-0095-6

Lin, J.-Y., Kuo, R.-L., and Huang, H.-I. (2019). Activation of Type I Interferon Antiviral Response in Human Neural Stem Cells. Stem Cell Res Ther 10 (1), 387. doi:10.1186/s13287-019-1521-5

Liu, H. (2013). Preclinical Evaluation of Herpes Simplex Virus Armed with Granulocyte-Macrophage colony-stimulating Factor in Pancreatic Carcinoma. Wjg 19 (31), 5138-5143. doi:10.3748/wjg.v19.i31.5138

Liu, M. A. (2019). A Comparison of Plasmid DNA and mRNA as Vaccine Technologies. Vaccines (Basel) 7 (2), 37. doi:10.3390/vaccines7020037

Liu, X. Y., and Gu, J. F. (2006). Targeting Gene-Virotherapy of Cancer. Cell Res 16 (1), 25-30. doi:10.1038/sj.cr.7310005

Liu, Z., Ravindranathan, R., Kalinski, P., Guo, Z. S., and Bartlett, D. L. (2017). Rational Combination of Oncolytic Vaccinia Virus and PD-L1 Blockade Works Synergistically to Enhance Therapeutic Efficacy. Nat. Commun. 8, 14754. doi:10.1038/ncomms 14754

Longo, S. L., Griffith, C., Glass, A., Shillitoe, E. J., and Post, D. E. (2011). Development of an Oncolytic Herpes Simplex Virus Using a Tumor-specific HIF-Responsive Promoter. Cancer Gene Ther. 18 (2), 123-134. doi:10.1038/ cgt.2010.62

Lorence, R. M., Pecora, A. L., Major, P. P., Hotte, S. J., Laurie, S. A., Roberts, M. S., et al. (2003). Overview of Phase I Studies of Intravenous Administration of PV701, an Oncolytic Virus. Curr. Opin. Mol. Ther. 5 (6), 618-624.

Lou, Z., Gong, Y. Q., Zhou, X., and Hu, G. H. (2018). Low Expression of miR-199 in Hepatocellular Carcinoma Contributes to Tumor Cell Hyper-Proliferation by Negatively Suppressing XBP1. Oncol. Lett. 16 (5), 6531-6539. doi:10.3892/ ol.2018.9476

Lugano, R., Ramachandran, M., and Dimberg, A. (2020). Tumor Angiogenesis: Causes, Consequences, Challenges and Opportunities. Cell. Mol. Life Sci. 77 (9), 1745-1770. doi:10.1007/s00018-019-03351-7

Macedo, N., Miller, D. M., Haq, R., and Kaufman, H. L. (2020). Clinical Landscape of Oncolytic Virus Research in 2020. J. Immunother. Cancer 8 (2), e001486. doi:10.1136/jitc-2020-001486

Mahalingam, D., Wilkinson, G. A., Eng, K. H., Fields, P., Raber, P., Moseley, J. L., et al. (2020). Pembrolizumab in Combination with the Oncolytic Virus Pelareorep and Chemotherapy in Patients with Advanced Pancreatic Adenocarcinoma: A Phase Ib Study. Clin. Cancer Res. 26 (1), 71-81. doi:10.1158/1078-0432.ccr-19-2078

Marino, N., Illingworth, S., Kodialbail, P., Patel, A., Calderon, H., Lear, R., et al. (2017). Development of a Versatile Oncolytic Virus Platform for Local Intratumoural Expression of Therapeutic Transgenes. PLoS One 12 (5), e0177810. doi:10.1371/journal.pone.0177810

Markert, J. M., Liechty, P. G., Wang, W., Gaston, S., Braz, E., Karrasch, M., et al. (2009). Phase Ib Trial of Mutant Herpes Simplex Virus G207 Inoculated Preand post-tumor Resection for Recurrent GBM. Mol. Ther. 17 (1), 199-207. doi:10.1038/mt.2008.228

Marrugal-Lorenzo, J. A., Serna-Gallego, A., Berastegui-Cabrera, J., Pachón, J., and Sánchez-Céspedes, J. (2019). Repositioning Salicylanilide Anthelmintic Drugs to Treat Adenovirus Infections. Sci. Rep. 9 (1), 17. doi:10.1038/s41598-01837290-3

Marshall, E. (2002). Cancer Therapy. Setbacks for Endostatin. Science 295 (5563), 2198-2199. doi:10.1126/science.295.5563.2198

McNamara, M. A., Nair, S. K., and Holl, E. K. (20152015). RNA-based Vaccines in Cancer Immunotherapy. J. Immunol. Res. 2015, 794528. doi:10.1155/2015/ 794528

Mell, L. K., Brumund, K. T., Daniels, G. A., Advani, S. J., Zakeri, K., Wright, M. E., et al. (2017). Phase I Trial of Intravenous Oncolytic Vaccinia Virus (GL-ONC1) with Cisplatin and Radiotherapy in Patients with Locoregionally Advanced Head and Neck Carcinoma. Clin. Cancer Res. 23 (19), 5696-5702. doi:10.1158/ 1078-0432.ccr-16-3232

Menotti, L., Nicoletti, G., Gatta, V., Croci, S., Landuzzi, L., De Giovanni, C., et al. (2009). Inhibition of Human Tumor Growth in Mice by an Oncolytic Herpes Simplex Virus Designed to Target Solely HER-2-Positive Cells. Proc. Natl. Acad. Sci. 106 (22), 9039-9044. doi:10.1073/pnas.0812268106
Mineta, T., Rabkin, S. D., Yazaki, T., Hunter, W. D., and Martuza, R. L. (1995). Attenuated Multi-Mutated Herpes Simplex Virus-1 for the Treatment of Malignant Gliomas. Nat. Med. 1 (9), 938-943. doi:10.1038/nm0995-938

Miranda-Saksena, M., Denes, C. E., Diefenbach, R. J., and Cunningham, A. L. (2018). Infection and Transport of Herpes Simplex Virus Type 1 in Neurons: Role of the Cytoskeleton. Viruses 10 (2). doi:10.3390/v10020092

Mok, W., Boucher, Y., and Jain, R. K. (2007). Matrix Metalloproteinases-1 and -8 Improve the Distribution and Efficacy of an Oncolytic Virus. Cancer Res. 67 (22), 10664-10668. doi:10.1158/0008-5472.can-07-3107

Msaouel, P., Iankov, I. D., Allen, C., Aderca, I., Federspiel, M. J., Tindall, D. J., et al. (2009). Noninvasive Imaging and Radiovirotherapy of Prostate Cancer Using an Oncolytic Measles Virus Expressing the Sodium Iodide Symporter. Mol. Ther. 17 (12), 2041-2048. doi:10.1038/mt.2009.218

Müller, L., Berkeley, R., Barr, T., Ilett, E., and Errington-Mais, F. (2020). Past, Present and Future of Oncolytic Reovirus. Cancers (Basel) 12 (11), 3219. doi:10.3390/cancers 12113219

Müller, L. M. E., Holmes, M., Michael, J. L., Scott, G. B., West, E. J., Scott, K. J., et al. (2019). Plasmacytoid Dendritic Cells Orchestrate Innate and Adaptive Antitumor Immunity Induced by Oncolytic Coxsackievirus A21. J. Immunother. Cancer 7 (1), 164. doi:10.1186/s40425-019-0632-y

Murphy, J. P., Kim, Y., Clements, D. R., Konda, P., Schuster, H., Kowalewski, D. J., et al. (2019). Therapy-Induced MHC I Ligands Shape Neo-Antitumor CD8 $\mathrm{T}$ Cell Responses during Oncolytic Virus-Based Cancer Immunotherapy. J. Proteome Res. 18 (6), 2666-2675. doi:10.1021/acs.jproteome.9b00173

Nakao, A., Takeda, S., Shimoyama, S., Kasuya, H., Kimata, H., Teshigahara, O., et al. (2007). Clinical experiment of Mutant Herpes Simplex Virus HF10 Therapy for Cancer. Ccdt 7 (2), 169-174. doi:10.2174/ 156800907780058808

Nguyên, T. L. A., Abdelbary, H., Arguello, M., Breitbach, C., Leveille, S., Diallo, J.S., et al. (2008). Chemical Targeting of the Innate Antiviral Response by Histone Deacetylase Inhibitors Renders Refractory Cancers Sensitive to Viral Oncolysis. Proc. Natl. Acad. Sci. U S A. 105 (39), 14981-14986. doi:10.1073/ pnas. 0803988105

Nikolic, J., Belot, L., Raux, H., Legrand, P., Gaudin, Y., and A. Albertini, A. (2018). Structural Basis for the Recognition of LDL-Receptor Family Members by VSV Glycoprotein. Nat. Commun. 9 (1), 1029. doi:10.1038/s41467-018-03432-4

Nishio, N., and Dotti, G. (2015). Oncolytic Virus Expressing RANTES and IL-15 Enhances Function of CAR-Modified $\mathrm{T}$ Cells in Solid Tumors. Oncoimmunology 4 (2), e988098. doi:10.4161/21505594.2014.988098

Oikonomou, E., and Pintzas, A. (2013). The TRAIL of Oncogenes to Apoptosis. Biofactors 39 (4), 343-354. doi:10.1002/biof.1112

Pan, W., Bodempudi, V., Esfandyari, T., and Farassati, F. (2009). Utilizing Ras Signaling Pathway to Direct Selective Replication of Herpes Simplex Virus-1. PLoS One 4 (8), e6514. doi:10.1371/journal.pone.0006514

Pardee, A. D., Yano, H., Weinstein, A. M., Ponce, A. A. K., Ethridge, A. D., Normolle, D. P., et al. (2015). Route of Antigen Delivery Impacts the Immunostimulatory Activity of Dendritic Cell-Based Vaccines for Hepatocellular Carcinoma. J. Immunotherapy Cancer 3, 32. doi:10.1186/ s40425-015-0077-x

Park, A. K., Fong, Y., Kim, S. I., Yang, J., Murad, J. P., Lu, J., et al. (2020). Effective Combination Immunotherapy Using Oncolytic Viruses to Deliver CAR Targets to Solid Tumors. Sci. Transl Med. 12 (559). doi:10.1126/scitranslmed.aaz1863

Park, S. H., Breitbach, C. J., Lee, J., Park, J. O., Lim, H. Y., Kang, W. K., et al. (2015). Phase $1 \mathrm{~b}$ Trial of Biweekly Intravenous Pexa-Vec (JX-594), an Oncolytic and Immunotherapeutic Vaccinia Virus in Colorectal Cancer. Mol. Ther. 23 (9), 1532-1540. doi:10.1038/mt.2015.109

Parvez, M. K. (2020). Geometric Architecture of Viruses. Wjv 9 (2), 5-18. doi:10.5501/wjv.v9.i2.5

Pecora, A. L., Rizvi, N., Cohen, G. I., Meropol, N. J., Sterman, D., Marshall, J. L., et al. (2002). Phase I Trial of Intravenous Administration of PV701, an Oncolytic Virus, in Patients with Advanced Solid Cancers. Jco 20 (9), 2251-2266. doi:10.1200/jco.2002.08.042

Pencavel, T. D., Wilkinson, M. J., Mansfield, D. C., Khan, A. A., Seth, R., Karapanagiotou, E. M., et al. (2015). Isolated Limb Perfusion with Melphalan, Tumour Necrosis Factor-Alpha and Oncolytic Vaccinia Virus Improves Tumour Targeting and Prolongs Survival in a Rat Model of Advanced Extremity Sarcoma. Int. J. Cancer 136 (4), 965-976. doi:10.1002/ ijc.29059 
Peng, K.-W., Hadac, E. M., Anderson, B. D., Myers, R., Harvey, M., Greiner, S. M., et al. (2006). Pharmacokinetics of Oncolytic Measles Virotherapy: Eventual Equilibrium between Virus and Tumor in an Ovarian Cancer Xenograft Model. Cancer Gene Ther. 13 (8), 732-738. doi:10.1038/sj.cgt.7700948

Phuong, L. K., Allen, C., Peng, K. W., Giannini, C., Greiner, S., TenEyck, C. J., et al. (2003). Use of a Vaccine Strain of Measles Virus Genetically Engineered to Produce Carcinoembryonic Antigen as a Novel Therapeutic Agent against Glioblastoma Multiforme. Cancer Res. 63 (10), 2462-2469.

Poh, A. (2016). First Oncolytic Viral Therapy for Melanoma. Cancer Discov. 6 (1), 6. doi:10.1158/2159-8290.CD-NB2015-158

Power, A. T., and Bell, J. C. (2008). Taming the Trojan Horse: Optimizing Dynamic Carrier Cell/oncolytic Virus Systems for Cancer Biotherapy. Gene Ther. 15 (10), 772-779. doi:10.1038/gt.2008.40

Prestwich, R. J., Errington, F., Diaz, R. M., Pandha, H. S., Harrington, K. J., Melcher, A. A., et al. (2009). The Case of Oncolytic Viruses versus the Immune System: Waiting on the Judgment of Solomon. Hum. Gene Ther. 20 (10), 1119-1132. doi:10.1089/hum.2009.135

Qian, C.-N., and Pezzella, F. (2018). Tumor Vasculature: a Sally Port for Inhibiting Cancer Cell Spreading. Cancer Commun. 38 (1), 52. doi:10.1186/s40880-0180322-z

Qian, J., Yang, J., Dragovic, A. F., Abu-Isa, E., Lawrence, T. S., and Zhang, M. (2005). Ionizing Radiation-Induced Adenovirus Infection Is Mediated by Dynamin 2. Cancer Res. 65 (13), 5493-5497. doi:10.1158/0008-5472.can-044526

Qiao, J., Wang, H., Kottke, T., White, C., Twigger, K., Diaz, R. M., et al. (2008). Cyclophosphamide Facilitates Antitumor Efficacy against Subcutaneous Tumors Following Intravenous Delivery of Reovirus. Clin. Cancer Res. 14 (1), 259-269. doi:10.1158/1078-0432.ccr-07-1510

Raja, J., Ludwig, J. M., Gettinger, S. N., Schalper, K. A., and Kim, H. S. (2018). Oncolytic Virus Immunotherapy: Future Prospects for Oncology. J. Immunotherapy Cancer 6 (1), 140. doi:10.1186/s40425-018-0458-z

Ramelyte, E., Tastanova, A., Balázs, Z., Ignatova, D., Turko, P., Menzel, U., et al. (2021). Oncolytic Virotherapy-Mediated Anti-tumor Response: a Single-Cell Perspective. Cancer Cell 39 (3), 394-406.e4. doi:10.1016/j.ccell.2020.12.022

Ramesh, N., Ge, Y., Ennist, D. L., Zhu, M., Mina, M., Ganesh, S., et al. (2006). CG0070, a Conditionally Replicating Granulocyte Macrophage ColonyStimulating Factor-Armed Oncolytic Adenovirus for the Treatment of Bladder Cancer. Clin. Cancer Res. 12 (1), 305-313. doi:10.1158/10780432.ccr-05-1059

Restifo, N. P., Dudley, M. E., and Rosenberg, S. A. (2012). Adoptive Immunotherapy for Cancer: Harnessing the T Cell Response. Nat. Rev. Immunol. 12 (4), 269-281. doi:10.1038/nri3191

Ribas, A., Dummer, R., Puzanov, I., VanderWalde, A., Andtbacka, R. H. I., Michielin, O., et al. (2017). Oncolytic Virotherapy Promotes Intratumoral $\mathrm{T}$ Cell Infiltration and Improves Anti-PD-1 Immunotherapy. Cell 170 (6), 1109-1119.e10. doi:10.1016/j.cell.2017.08.027

Ruano, D., López-Martín, J. A., Moreno, L., Lassaletta, Á., Bautista, F., Andión, M., et al. (2020). First-in-Human, First-In-Child Trial of Autologous MSCs Carrying the Oncolytic Virus Icovir-5 in Patients with Advanced Tumors. Mol. Ther. 28 (4), 1033-1042. doi:10.1016/j.ymthe.2020.01.019

Ruiz, A. J., and Russell, S. J. (2015). MicroRNAs and Oncolytic Viruses. Curr. Opin. Virol. 13, 40-48. doi:10.1016/j.coviro.2015.03.007

Saha, D., Martuza, R. L., and Rabkin, S. D. (2017). Macrophage Polarization Contributes to Glioblastoma Eradication by Combination Immunovirotherapy and Immune Checkpoint Blockade. Cancer Cell 32 (2), 253-267.e5. doi:10.1016/j.ccell.2017.07.006

Samson, A., Scott, K. J., Taggart, D., West, E. J., Wilson, E., Nuovo, G. J., et al. (2018). Intravenous Delivery of Oncolytic Reovirus to Brain Tumor Patients Immunologically Primes for Subsequent Checkpoint Blockade. Sci. Transl Med. 10 (422), eaam7577. doi:10.1126/scitranslmed.aam7577

Shen, W., Wang, C.-Y., Wang, X.-H., and Fu, Z.-X. (2009). Oncolytic Adenovirus Mediated Survivin Knockdown by RNA Interference Suppresses Human Colorectal Carcinoma Growth In Vitro and In Vivo. J. Exp. Clin. Cancer Res. 28 (1), 81. doi:10.1186/1756-9966-28-81

Shmulevitz, M., Marcato, P., and Lee, P. W. K. (2005). Unshackling the Links between Reovirus Oncolysis, Ras Signaling, Translational Control and Cancer. Oncogene 24 (52), 7720-7728. doi:10.1038/sj.onc.1209041
Siegel, R. L., Miller, K. D., Fuchs, H. E., and Jemal, A. (2021). Cancer Statistics, 2021. CA A. Cancer J. Clin. 71 (1), 7-33. doi:10.3322/caac.21654

Song, K., and Viskovska, M. (2020). Design and Engineering of Deimmunized Vaccinia Viral Vectors. Biomedicines 8 (11), 491. doi:10.3390/ biomedicines8110491

Song, X., Wang, H., Jia, R., Cun, B., Zhao, X., Zhou, Y., et al. (2012). Combined Treatment with an Oncolytic Adenovirus and Antitumor Activity of Vincristine against Retinoblastoma Cells. Ijms 13 (9), 10736-10749. doi:10.3390/ijms130910736

Sterman, D. H., Recio, A., Carroll, R. G., Gillespie, C. T., Haas, A., Vachani, A., et al. (2007). A Phase I Clinical Trial of Single-Dose Intrapleural IFN-Beta Gene Transfer for Malignant Pleural Mesothelioma and Metastatic Pleural Effusions: High Rate of Antitumor Immune Responses. Clin. Cancer Res. 13 (15 Pt 1), 4456-4466. doi:10.1158/1078-0432.CCR-07-0403

Stewart, J. H., Ahmed, M., Northrup, S. A., Willingham, M., and Lyles, D. S. (2011). Vesicular Stomatitis Virus as a Treatment for Colorectal Cancer. Cancer Gene Ther. 18 (12), 837-849. doi:10.1038/cgt.2011.49

Su, C., and Zheng, C. (2017). Herpes Simplex Virus 1 Abrogates the cGAS/STINGMediated Cytosolic DNA-Sensing Pathway via its Virion Host Shutoff Protein, UL41. J. Virol. 91 (6). doi:10.1128/jvi.02414-16

Touchefeu, Y., Vassaux, G., and Harrington, K. J. (2011). Oncolytic Viruses in Radiation Oncology. Radiother. Oncol. 99 (3), 262-270. doi:10.1016/ j.radonc.2011.05.078

Tsukuda, K., Wiewrodt, R., Molnar-Kimber, K., Jovanovic, V. P., and Amin, K. M. (2002). An E2F-Responsive Replication-Selective Adenovirus Targeted to the Defective Cell Cycle in Cancer Cells: Potent Antitumoral Efficacy but No Toxicity to normal Cell. Cancer Res. 62 (12), 3438-3447.

Uchida, H., Marzulli, M., Nakano, K., Goins, W. F., Chan, J., Hong, C.-S., et al. (2013). Effective Treatment of an Orthotopic Xenograft Model of Human Glioblastoma Using an EGFR-Retargeted Oncolytic Herpes Simplex Virus. Mol. Ther. 21 (3), 561-569. doi:10.1038/mt.2012.211

Ulasov, I. V., Zhu, Z. B., Tyler, M. A., Han, Y., Rivera, A. A., Khramtsov, A., et al. (2007). Survivin-driven and Fiber-Modified Oncolytic Adenovirus Exhibits Potent Antitumor Activity in Established Intracranial Glioma. Hum. Gene Ther. 18 (7), 589-602. doi:10.1089/hum.2007.002

Ungerechts, G., Bossow, S., Leuchs, B., Holm, P. S., Rommelaere, J., Coffey, M., et al. (2016). Moving Oncolytic Viruses into the Clinic: Clinical-Grade Production, Purification, and Characterization of Diverse Oncolytic Viruses. Mol. Ther. - Methods Clin. Dev. 3, 16018. doi:10.1038/mtm.2016.18

Velazquez-Salinas, L., Naik, S., Pauszek, S. J., Peng, K.-W., Russell, S. J., and Rodriguez, L. L. (2017). Oncolytic Recombinant Vesicular Stomatitis Virus (VSV) Is Nonpathogenic and Nontransmissible in Pigs, a Natural Host of VSV. Hum. Gene Ther. Clin. Dev. 28 (2), 108-115. doi:10.1089/humc.2017.015

Wang, H., Song, X., Zhang, H., Zhang, J., Shen, X., Zhou, Y., et al. (2012). Potentiation of Tumor Radiotherapy by a Radiation-Inducible Oncolytic and Oncoapoptotic Adenovirus in Cervical Cancer Xenografts. Int. J. Cancer 130 (2), 443-453. doi:10.1002/ijc.26013

Wei, D., Li, Q., Wang, X.-L., Wang, Y., Xu, J., Feng, F., et al. (2015). Oncolytic Newcastle Disease Virus Expressing Chimeric Antibody Enhanced Anti-tumor Efficacy in Orthotopic Hepatoma-Bearing Mice. J. Exp. Clin. Cancer Res. 34, 153. doi:10.1186/s13046-015-0271-1

Willmon, C. L., Saloura, V., Fridlender, Z. G., Wongthida, P., Diaz, R. M., Thompson, J., et al. (2009). Expression of IFN- $\beta$ Enhances Both Efficacy and Safety of Oncolytic Vesicular Stomatitis Virus for Therapy of Mesothelioma. Cancer Res. 69 (19), 7713-7720. doi:10.1158/0008-5472.can09-1013

Wing, A., Fajardo, C. A., Posey, A. D., Shaw, C., Da, T., Young, R. M., et al. (2018). Improving CART-Cell Therapy of Solid Tumors with Oncolytic Virus-Driven Production of a Bispecific T-Cell Engager. Cancer Immunol. Res. 6 (5), 605-616. doi:10.1158/2326-6066.cir-17-0314

Xia, M., Luo, D., Dong, J., Zheng, M., Meng, G., Wu, J., et al. (2019). Graphene Oxide Arms Oncolytic Measles Virus for Improved Effectiveness of Cancer Therapy. J. Exp. Clin. Cancer Res. 38 (1), 408. doi:10.1186/s13046-019-1410-x

Yang, Y., Xu, W., Neill, T., Hu, Z., Wang, C.-H., Xiao, X., et al. (2015). Systemic Delivery of an Oncolytic Adenovirus Expressing Decorin for the Treatment of Breast Cancer Bone Metastases. Hum. Gene Ther. 26 (12), 813-825. doi:10.1089/hum.2015.098 
Yao, W., Guo, G., Zhang, Q., Fan, L., Wu, N., and Bo, Y. (2014). The Application of Multiple miRNA Response Elements Enables Oncolytic Adenoviruses to Possess Specificity to Glioma Cells. Virology 458-459, 69-82. doi:10.1016/ j.virol.2014.04.007

Yao, Y., Wang, L., Zhang, H., Wang, H., Zhao, X., Zhang, Y., et al. (2012). A Novel Anticancer Therapy that Simultaneously Targets Aberrant P53 and Notch Activities in Tumors. PLoS One 7 (10), e46627. doi:10.1371/ journal.pone.0046627

Ye, Z., Wang, X., Hao, S., Zhong, J., Xiang, J., and Yang, J. (2006). Oncolytic Adenovirus-Mediated E1A Gene Therapy Induces Tumor-Cell Apoptosis and Reduces Tumor Angiogenesis Leading to Inhibition of Hepatocellular Carcinoma Growth in Animal Model. Cancer Biother. Radiopharm. 21 (3), 225-234. doi:10.1089/cbr.2006.21.225

Yoo, J.-K., Kim, T. S., Hufford, M. M., and Braciale, T. J. (2013). Viral Infection of the Lung: Host Response and Sequelae. J. Allergy Clin. Immunol. 132 (6), 1263-1276. doi:10.1016/j.jaci.2013.06.006

Yoon, T.-K. L., Shichinohe, T., Laquerre, S., and Kasahara, N. (2001). Selectively Replicating Adenoviruses for Oncolytic Therapy. Ccdt 1 (2), 85-107. doi:10.2174/1568009013334223

Yu, L., Baxter, P. A., Zhao, X., Liu, Z., Wadhwa, L., Zhang, Y., et al. (2011). A Single Intravenous Injection of Oncolytic Picornavirus SVV-001 Eliminates Medulloblastomas in Primary Tumor-Based Orthotopic Xenograft Mouse Models. Neuro-oncology 13 (1), 14-27. doi:10.1093/neuonc/noq148

Yu, M., Scherwitzl, I., Opp, S., Tsirigos, A., and Meruelo, D. (2019). Molecular and Metabolic Pathways Mediating Curative Treatment of a Non-hodgkin B Cell Lymphoma by Sindbis Viral Vectors and anti-4-1BB Monoclonal Antibody. J. Immunother. Cancer 7, 185. doi:10.1186/s40425-019-0664-3

Zhang, H., Wang, H., Zhang, J., Qian, G., Niu, B., Fan, X., et al. (2009). Enhanced Therapeutic Efficacy by Simultaneously Targeting Two Genetic Defects in Tumors. Mol. Ther. 17 (1), 57-64. doi:10.1038/mt.2008.236

Zhang, J.-F., Wei, F., Wang, H.-P., Li, H.-M., Qiu, W., Ren, P.-K., et al. (2010). Potent Anti-tumor Activity of Telomerase-dependent and HSV-TK Armed Oncolytic Adenovirus for Non-small Cell Lung Cancer In Vitro and In Vivo. J. Exp. Clin. Cancer Res. 29 (1), 52. doi:10.1186/1756-9966-29-52
Zhang, W., Ge, K., Zhao, Q., Zhuang, X., Deng, Z., Liu, L., et al. (2015). A Nove oHSV-1 Targeting Telomerase Reverse Transcriptase-Positive Cancer Cells via Tumor-specific Promoters Regulating the Expression of ICP4. Oncotarget 6 (24), 20345-20355. doi:10.18632/oncotarget.3884

Zhao, L., Dong, A., Gu, J., Liu, Z., Zhang, Y., Zhang, W., et al. (2006). The Antitumor Activity of TRAIL and IL-24 with Replicating Oncolytic Adenovirus in Colorectal Cancer. Cancer Gene Ther. 13 (11), 1011-1022. doi:10.1038/ sj.cgt.7700969

Zhou, Y., Song, X., Jia, R., Wang, H., Dai, L., Xu, X., et al. (2010). Radiationinducible Human Tumor Necrosis Factor-Related Apoptosis-Inducing Ligand (TRAIL) Gene Therapy: a Novel Treatment for Radioresistant Uveal Melanoma. Pigment Cell Melanoma Res 23 (5), 661-674. doi:10.1111/j.1755148x.2010.00729.x

Zhu, W., Wei, L., Zhang, H., Chen, J., and Qin, X. (2012). Oncolytic Adenovirus Armed with IL-24 Inhibits the Growth of Breast Cancer In Vitro and In Vivo. J. Exp. Clin. Cancer Res. 31 (1), 51. doi:10.1186/1756-9966-31-51

Conflict of Interest: The authors declare that the research was conducted in the absence of any commercial or financial relationships that could be construed as a potential conflict of interest.

Publisher's Note: All claims expressed in this article are solely those of the authors and do not necessarily represent those of their affiliated organizations, or those of the publisher, the editors, and the reviewers. Any product that may be evaluated in this article, or claim that may be made by its manufacturer, is not guaranteed or endorsed by the publisher.

Copyright (c) 2021 Yang, Gu, Yu, Ge and Fan. This is an open-access article distributed under the terms of the Creative Commons Attribution License (CC $B Y)$. The use, distribution or reproduction in other forums is permitted, provided the original author(s) and the copyright owner(s) are credited and that the original publication in this journal is cited, in accordance with accepted academic practice. No use, distribution or reproduction is permitted which does not comply with these terms. 


\section{GLOSSARY}

5-FU 5-fluorouracil

Ad-199T Adenovirus-199T

BBB Blood-brain barrier

CAR coxsackie-adenovirus receptor

CAR-T Chimeric Antigen Receptor T-Cell Immunotherapy

cGAS cyclic GMP-AMP synthase

CTL cytotoxic T lymphocyte

DAMP damage-associated molecular pattern

DC dendritic cell

DC-Mel dendritic cells loaded with human melanoma Mel888 cells

DCN decorin

dsDNA double-stranded DNA

dsRNA double-stranded RNA

ECM extracellular matrix

FDA Food and Drug Administration

FdUMP fluorodeoxyuracil monophosphate

FUTP fluorouracil triphosphate

HCC hepatocellular carcinoma

hTNF- $\boldsymbol{\alpha}$ human tumor necrosis factor $\alpha$

HSP Heat shock protein
HSV herpes simplex virus

ICB Immune checkpoint blockade

ICD immunogenic cell death

mDC mature dendritic cell

MV measles virus

NK natural killer cell

NDV newcastle disease virus

PAMP pathogen-associated molecular pattern

Pexa-Vec(JX-594) pexastimogene devacirepvec

ssDNA single-stranded DNA

ssRNA single-stranded RNA

STING stimulator of interferon genes

TAA tumor-associated antigen

TIL tumor infiltrating lymphocyte

UL41 HSV virion host shutoff protein

VAP virus adsorption protein

VCR vincristine

VDEPT virus-directed enzymatic prodrug therapy

VEGF vascular endothelial growth factor

VSV vesicular stomatitis virus

VV vaccinia virus 